\title{
A history of McMurdo Station through its architecture
}

\section{Georgina A. Davis}

\author{
College of Architecture, Texas A\&M University, College Station, TX 77840, USA \\ (georgina.davis@gmail.com)
}

\author{
Received May 2016; first published online 30 January 2017
}

\begin{abstract}
McMurdo Station, Antarctica, is a US Federal research facility operated year-round by the National Science Foundation (NSF). Its primary mission is to support scientific research, but it also provides logistical air and ground support for South Pole Station, seasonal field sites and nearby stations operated by other countries. It is the largest station in Antarctica, supporting up to 1,200 people. While McMurdo Station has a long scientific legacy, the facility also has an interesting architectural and engineering history that spans 60 years and has its antecedents in the 'heroic age' of exploration (1898-1916) and the Little America expeditions (1929-1958). Here, I describe the history of the built environment of McMurdo Station to clarify how it evolved from a temporary air station in the late 1950s to its current role as the flagship research facility of the US Antarctic Research Program (USAP). This historical review may provide insights that are useful as the station continues to transform and evolve, allowing it to continue its scientific mission into the 21 st century.
\end{abstract}

\section{Introduction}

Nearly every description of Antarctica begins with a list of the continent's extremes: temperature, wind speed, average altitude and relative humidity. It boasts of no early human history and therefore has no cultural artefacts, traditions or memory of armed conflict. Unlike the Arctic, Antarctica remained isolated from early humans, covered in perpetual ice and surrounded by the tempestuous Southern Ocean. Although Antarctica has a rich and colourful recent history, it barely spans 200 years. With no local building materials or agriculture, everything must be imported. As with space travel, being in Antarctica is something humans can only do with great effort and logistical support, for the landscape, while striking, is both desolate and unforgiving. The same beauty captured in countless photographs over the last century can be a dangerous distraction from the fact that, if cut off from outside world, people face grim prospects and no chance of long-term survival. However, as with space travel, we have advanced from small, cramped enclosures to larger, modern research facilities. The focus today has shifted from mere survival and 'getting by' to one of long-term occupation (that is creating a sense of place in an alien environment and making it sustainable).

The US government's McMurdo Station, located on Ross Island in Antarctica, is the largest and one of the most remote research facilities on the continent. Each year it serves as an important laboratory and logistical hub for hundreds of scientists from around the world conducting research on and around Ross Island and as far away as South Pole station (1350 km or 729 nautical miles away). More like a small town than any other Antarctic station, McMurdo was established in the 1950s under the direction of the US Navy (USN); later it was transferred to the NSF. Today the station supports a summer population of approximately 1,200 and a winter population of about 200 civilian support personnel and a few scientists. The station's design, construction and renovations have evolved over half a century with a succession of master plans and single building renovations and replacements.

For those unfamiliar with the history of McMurdo Station, as one of the oldest, continuously operational stations on the continent, the choices behind the station's current design and the geopolitical and scientific motivations for maintaining its presence have not always been clear. The purpose of this article is to combine architectural information from many sources to create a previously unavailable historical record of how building types and technology have changed at McMurdo Station as it progressed from a small military camp of temporary huts to a permanent research station housing hundreds of people year-round. As such, it should be useful when creating and evaluating future designs for the station.

\section{Early explorers and the built environment}

Ross Island is named for Captain James Clark Ross who first visited the area aboard the HMS Erebus and HMS Terror in 1841. He named the sound along the west coast of the island, which is frozen most of the year, after his lieutenant on board Terror, Archibald McMurdo. The east coast of Ross Island is locked in thick, permanent ice. Ross never set foot on the island but named the two volcanic peaks Mount Erebus and Mount Terror after his vessels (Neider 1974: 17). In Greek mythology, Erebus was the gatekeeper to the underworld, a fitting name for the smouldering sentinel he discovered at the edge of the great ice barrier, known today as the Ross Ice Shelf.

The continent of Antarctica remained relatively unexplored for five more decades except for whalers and sealers who flocked to the rich coastal waters in search of fur seal skins and oil from elephant seals and whales. The first wave of Antarctic exploration, generally known as the 'heroic age' began in 1895. At this time, there were still lands around the world to be explored, claimed and conquered; even the North Pole had not yet been attained. Those drawn to the South Pole went in search of adventure, 


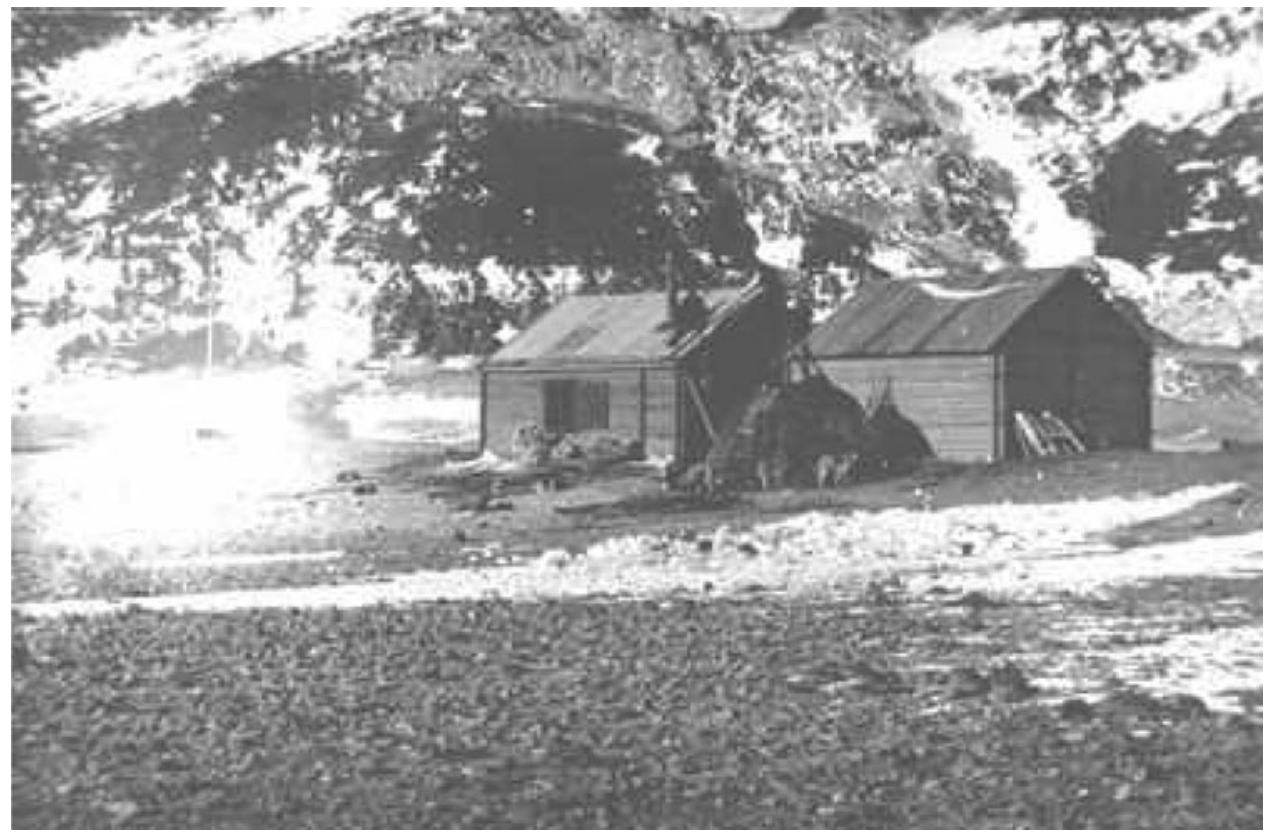

Fig. 1. The first building in Antarctica, at Cape Adare, Victoria Land, built in 1889 , is an example of a Scandinavian-style Antarctic hut. Reprinted with permission of David L. Harrowfield.

glory and, to an extent, scientific recognition. The name itself, 'heroic age', bestows upon those early journeys a great sense of romantic adventure, and when reading the first-hand accounts of these men it becomes clear that they found it and much more.

These explorers sailed to the southern continent and established base camps along the coast that allowed small, exploratory teams to penetrate deeper into this strange, inhospitable land. Over time, the coast of Antarctica became an icy time capsule for the few surviving buildings and memorials from this period, all in various stages of disrepair, but mostly well preserved by the cold, dry air and the efforts of preservationists. People working at today's modern Antarctic stations, complete with power, heat and nearly every modern convenience, including the internet, can visit these historic sites as tourists. These buildings are often labelled 'monuments to the human spirit' despite their humble classification as 'huts'.

These historical huts offer insight into the past and show what was humanly possible even under the most extreme and remote conditions. Importantly, they also reveal problems that would again plague the buildings used in next wave of Antarctic exploration: site selection, transport of materials, ease of construction, extreme temperatures, high winds and blowing snow, ventilation, privacy, segregation and thermal comfort. Pearson (1992) categorised the huts into three styles: Scandinavian, British and Australian; each with its own characteristics, design successes and shortcomings. Each provides valuable information that helped pave the way for future explorers to survive the climate and the long, dark winters.

Scandinavian-style Antarctic huts had heavy plank walls with cellulose-based insulation, gabled roofs with lofts, no veranda, oil-burning lamps and a spatial organisation that did not separate sailors from officers. Two examples of this style include the huts built by Carsten Borchgrevink in 1889 and Roald Amundsen in 1910 (Figs 1 and 2). Borchgrevink's camp at Cape Adare is now considered the first building in Antarctica.

British-style huts, lashed down with ropes, had timber frames clapped with weatherboarding and insulation, gabled roofs without lofts, protected entrances without a veranda, acetylene lighting and a spatial organisation that separated the officers from the sailors. Two examples of this style include the huts built by Ernest Shackleton in 1908 and Robert Falcon Scott in 1911 (Figs 3 and 4).

Australian-style huts had timber frames insulated with felt or cork, a pyramidal roof over a large square area, a veranda on three sides, framing posts sunk into the ground and a spatial organisation that separated the party leaders from the other personnel. Two examples of this style include the huts built by Scott in 1901 and Douglas Mawson in 1911 (Figs 5 and 6).

These three styles of huts each have their strengths and weaknesses, but it is clear that maintaining a balance between comfortable temperatures and healthy ventilation rates was one of the challenges faced by these expeditions. Only one hut, Amundsen's Framheim, successfully achieved this balance, but did so in part by being subnivean with a working (if somewhat temperamental) ventilation system. Amundsen placed great importance on proper ventilation not only on his ship (Fram) but in their winter quarters (Framheim). He considered it a necessity for comfort and health, blaming reported health woes during other expeditions on poor ventilation (Amundsen 1913: 199). Even so, there was 


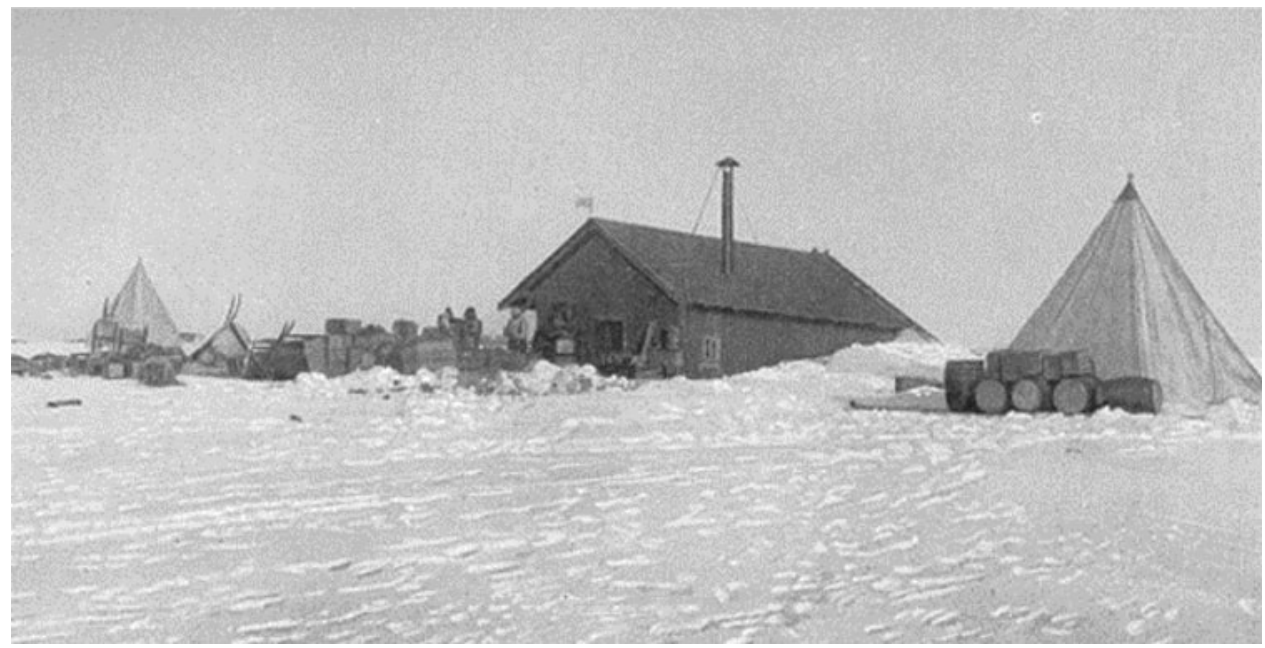

Fig. 2. Amundsen's base, Framheim, at the Bay of Whales was built in 1911 and is an example of a British-style Antarctic hut. Photo from The South Pole by Roald Amundsen 1913: 206.

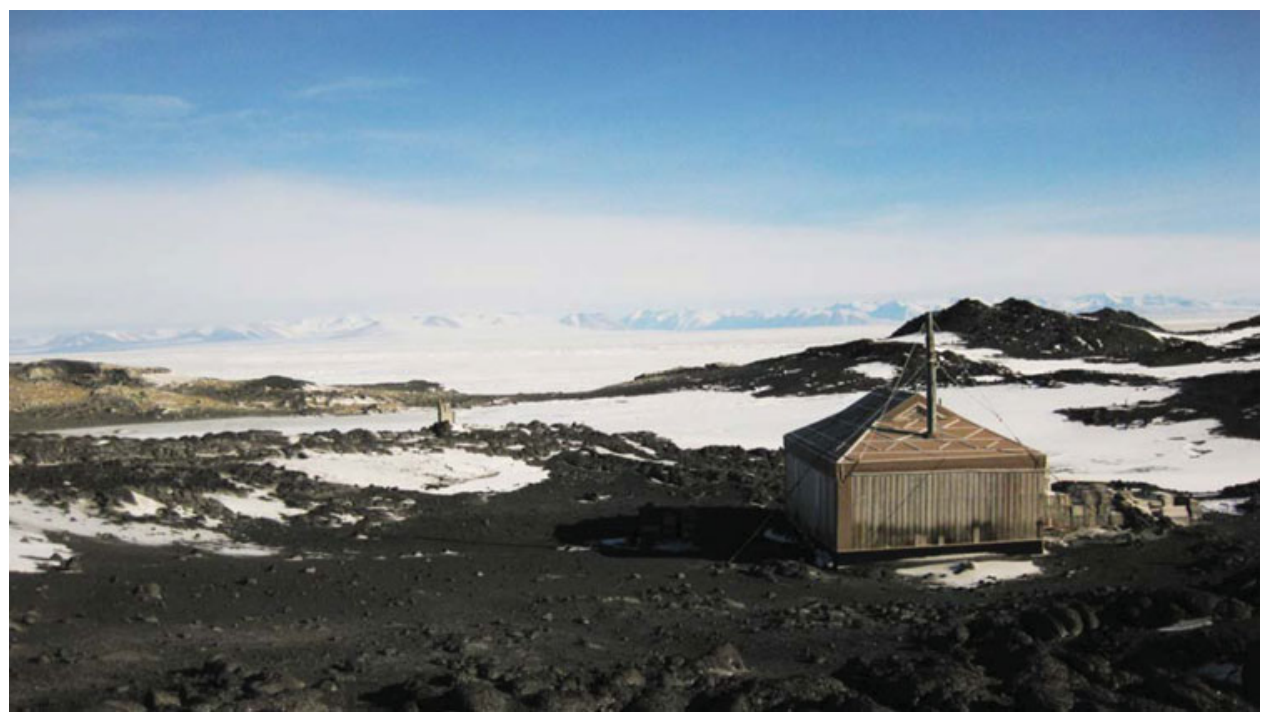

Fig. 3. Shackleton's hut at Cape Royds, Ross Island, was built in 1908 and is an example of a British-style Antarctic hut. (Photo by author, 2009).

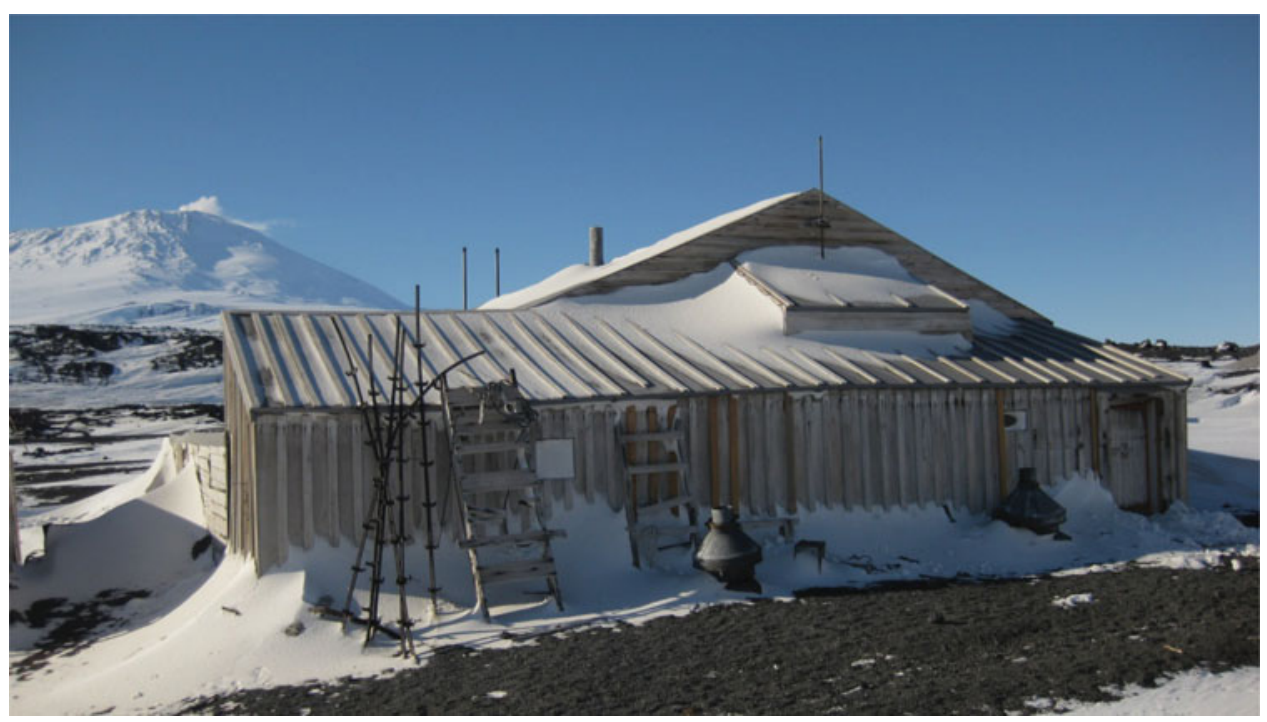

Fig. 4. Scott's hut at Cape Evans, was constructed in 1911 and is an example of a Britishstyle Antarctic hut. (Photo by author, 2009). 


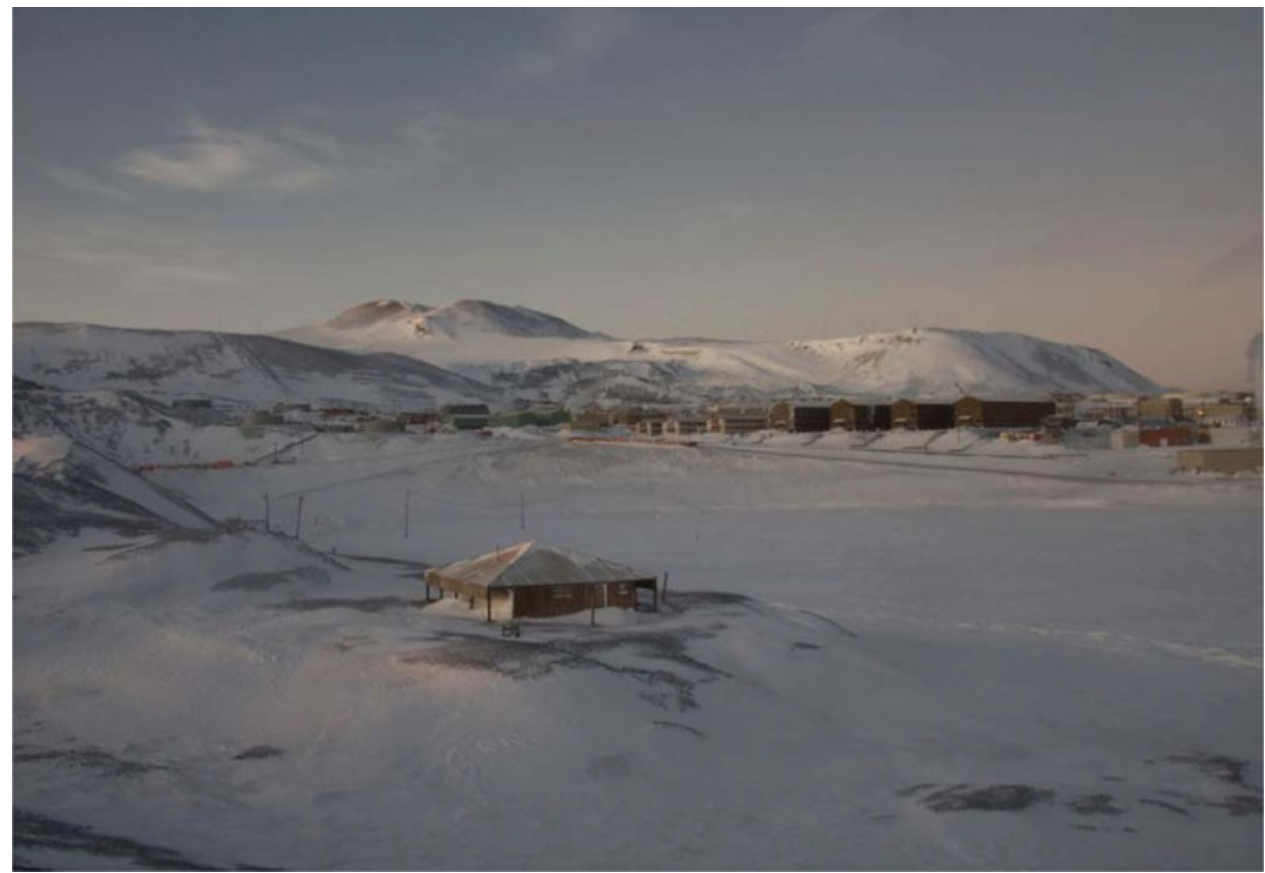

Fig. 5. Scott's Australian-style 1901 Discovery hut, Hut Point, Ross Island (foreground), and McMurdo Station (background) (Photo by D. Williams, 2009).

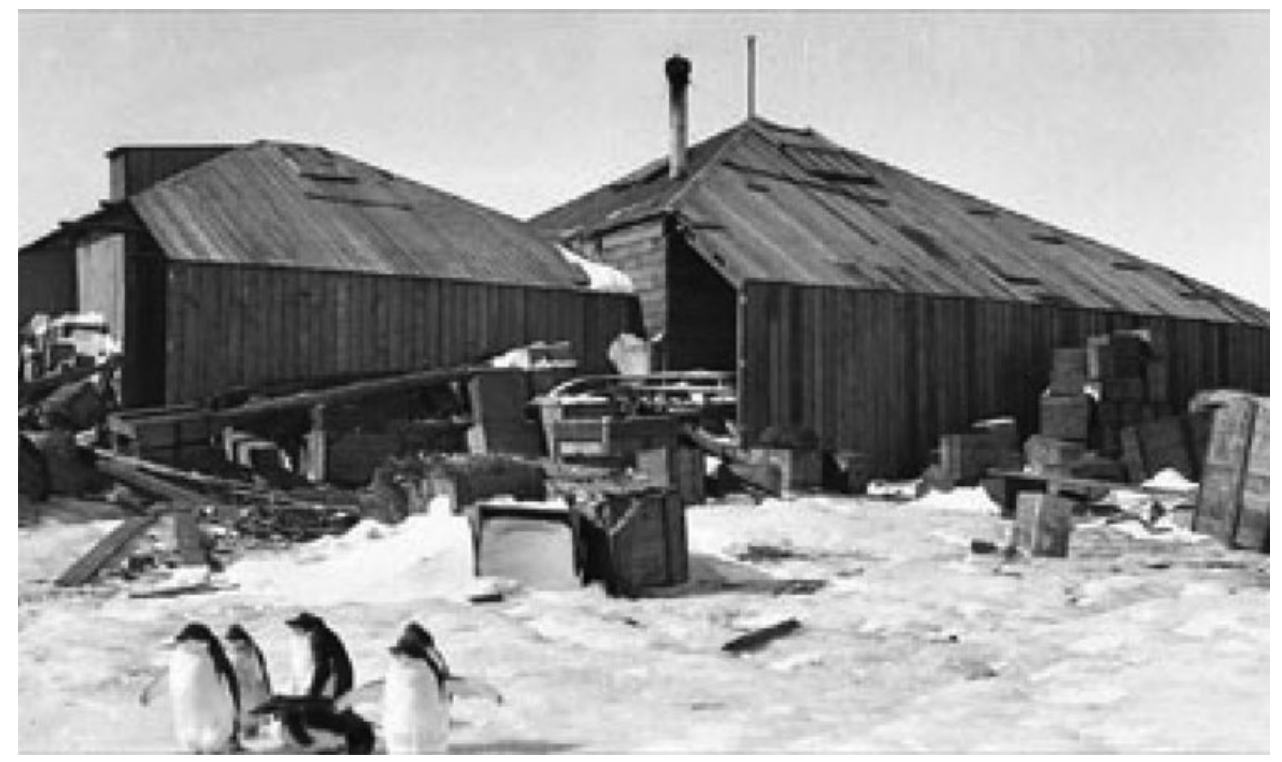

Fig. 6. Mawson's hut at Cape Denison, at the head of Commonwealth Bay, was built in 1911 and is an example of an Australian-style Antarctic hut. (image shows enclosed veranda).

still thermal stratification, a problem that persists in McMurdo today (mostly in older buildings).

Both Pearson (1992) and Harrowfield (1995) offer comprehensive reviews of Antarctica's first structures, looking not only at their historical importance and preservation but also construction methods, inspiration, lifespan, and their individual merits and drawbacks according to accounts from the men who lived in them. With this information in hand, it is possible to gain a better perspective of why these various huts differ in appearance and degrees of success.

\section{Naval air facility McMurdo Sound (1956-1961)}

Small Antarctic expeditions from the US were not uncommon between 1914 and 1940, but it was not until after World War II (WWII) that activity on the southern continent began to escalate. In the mid-1950s, the US began investing an enormous amount of time, energy and money in establishing a continuous Antarctic presence; it was in part a strategic military response to the Soviet Union during the Cold War in the years immediately following WWII (Collis and Stevens 2004: 4; Belanger 2006). The prize was a presence at the geographical South 
Pole, which was finally achieved in 1956. The logistics for this operation were only possible with an impressive show of manpower, air and naval support, and the construction and maintenance of a critical logistical hub located along the coast: Little America V on the Ross Ice Shelf.

For many years the geopolitics of Antarctica were unsettled, with a number of countries jostling for position. Until the Antarctic Treaty was signed in 1959 and went into effect in 1961, there were no internationally recognised laws governing the continent, including the presence of the military, the use of nuclear energy and testing, or mineral rights. The Treaty, signed initially by twelve countries, helped set a precedent that the continent would remain peaceful and devoted to scientific pursuits, such as the International Geophysical Year (IGY) from July 1957 to December 1958.

Admiral Richard Byrd, a naval officer and a veteran of Arctic exploration, had led early expeditions to Antarctica, establishing temporary 'Little America' bases from the late 1920s until the outbreak of WWII. These helped pave the way for eventual long-term occupation by the US postwar Antarctic expeditions to explore and establish more permanent bases. Byrd helped to organise the first of these operations, Operation Highjump (1946-1947), which:

'... was then (and remains) by far the largest Antarctic expedition, with more than 4,700 naval and marine personnel, 44 observers, 13 ships, and a number of aircraft ...' (OPP 1997: 17).

One of the goals ${ }^{1}$ was to determine the feasibility of establishing a semi-permanent ice base, Little America IV, for scientific research during the IGY (Hoffman 1974: 1). After more aerial photographs of the coastline were collected during a second expedition (Operation Windmill, 1947-1948) - an effort that aided in the final decision of where to locate a permanent station - Byrd led the first Operation Deep Freeze in 1955, which in December established Little America V and six other stations (that is, Byrd, South Pole, Ellsworth, Wilkes and Halley), including the first buildings of the Naval Air Facility, McMurdo Sound (NAF McMurdo).

NAF McMurdo and other bases erected as a part of the IGY were essentially temporary military field camps (Collis and Stevens 2004: 5). They supported scientific and logistical operations. Documents from the first years of Operation Deep Freeze indicate NAF McMurdo was neither a prominent research station nor a high-priority logistical hub (NRC 1957). It was important as an emergency landing point between other American bases, but Little America V was better positioned in relation to the South Pole and, being on the edge of the Ross Ice Shelf, it was easier to access by ship. It and other stations were supplied with more scientific equipment and accommodated more scientists. ${ }^{2}$

Then in 1961, changing snow and ice conditions made Little America V unusable for wheeled aircraft (Belanger 2006: 35), and snow accumulation threatened the structural safety of the station (Tyree, in Dempewolff 1961: 106). NAF McMurdo, built on the rocky shores of Ross Island, began to look more feasible for longterm occupation. ${ }^{3}$ The focus shifted away from Little America. No longer just an airfield, NAF McMurdo was renamed McMurdo Station in 1961 (Lagerbom n.d.; NRC 1957).

The 1956 layout for NAF McMurdo was a military grid roughly aligned along two parallel 'main streets', with a parade ground on one end and a makeshift chapel on the other (Collis and Stevens 2004: 3) (Fig. 7). There were roughly a dozen buildings accommodating approximately 130 men. Here, as with most other remote field stations, the buildings were separated to reduce the threat of spreading fire, but were still close enough to allow men to move conveniently among them in cold weather and to be seen easily in low-visibility conditions. The resultant layout was a variation of the more typical subnivean naval station, which tended to be physically connected, branching off a single, long axis corridor.

This corridor in McMurdo Station was not a protected structure, but an open 'street'. Unlike subnivean stations, which become buried within a matter of months, McMurdo was built on solid, exposed ground, a tiny speck on the steep shores of a massive volcanic island. In the early days of the station, the Army and US Naval Civil Engineering Laboratory (NCEL) manuals directed users to orient the longitudinal axis of buildings parallel to storm winds and perpendicular to east and northeast prevailing winds to prevent (or reduce) snow accumulation against entrances (Sherwood 1964a; 1964b; US Department of the Army 1957). It appears that this guideline was generally followed, and either by chance or by manpower, the grade of the coastline was nearly perpendicular to the prevailing wind direction.

Just as in some historic huts, NAF McMurdo barracks (Fig. 8), socialisation areas and even latrines were segregated by rank; for example, in the galley, officers ate separately from chiefs and lower-ranked men. Collis and Stevens describe the facility as essentially a '... pragmatic ...' naval establishment with '... tidy ...' rows of Quonset huts and prefabricated buildings (Collis and Stevens 2004: 3). There were also three separate bars for socialising. Scientists were able to move freely between all of these places, including an unofficial fourth bar set up by the pilots and crew who flew the flights in and out of McMurdo Station. These class distinctions no longer exist officially, but people still tend to create their own informal groups and status symbols.

Despite the high costs of perceived 'non-essential' buildings, the USN still understood (and researched) the need for immediate access to reasonably comfortable quarters and more than basic survival conditions for the men and officers (Sherwood 1964a: 1). Rear Admiral Dufek noted this when reflecting on his years leading Operation Deep Freeze. Writing of lessons learned during his first year, he wrote that while preparing for the second year of the operation, he decided that:

'[f]irst to go up would be the barracks and mess hall. Last year's experience taught us that the sooner the 

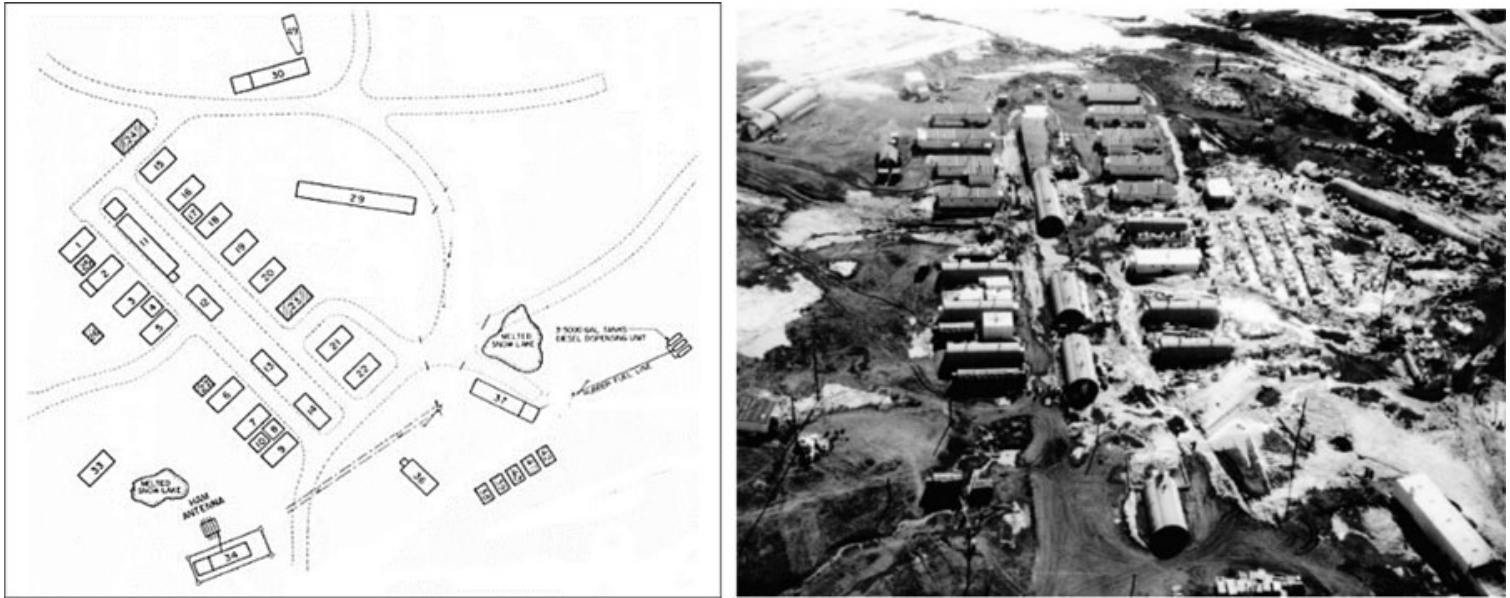

Fig. 7. (Left) Layout of NAF McMurdo Sound (NRC 1957: plate XI). (Right) Sky view of the McMurdo Sound Naval Air Facility in 1957.

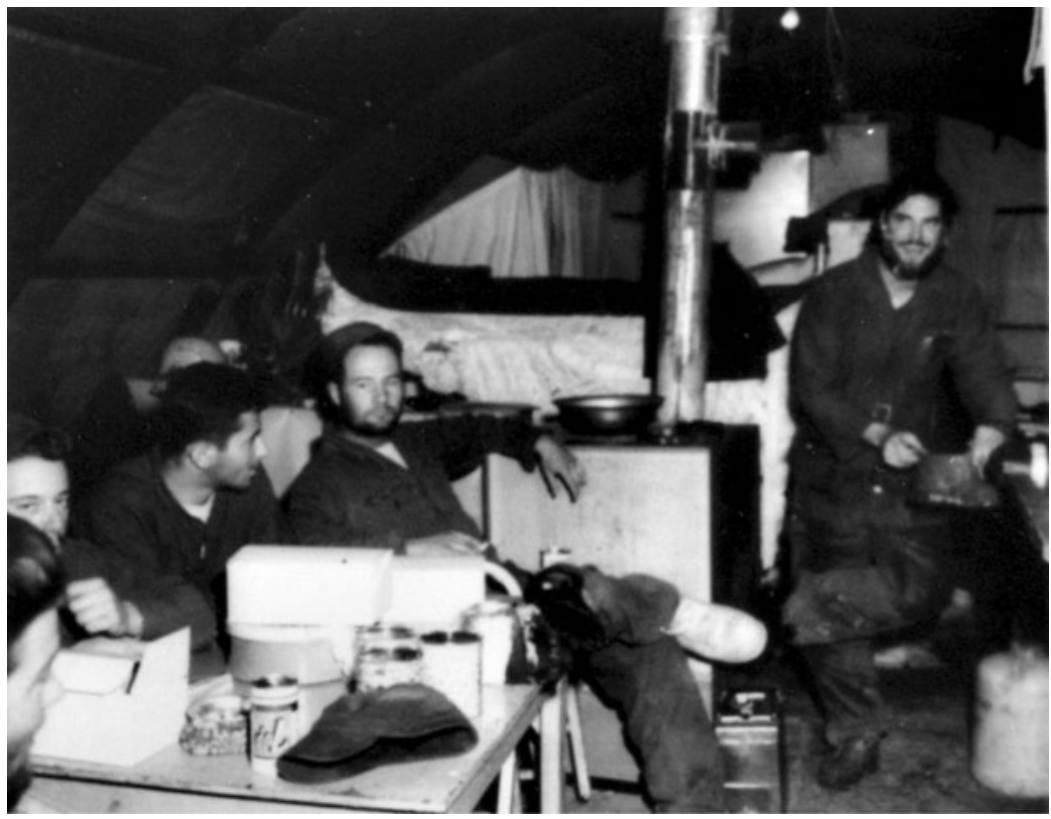

Fig. 8. Barrack J-24 floor space with ten bunks in the barracks and eight men assigned. McMurdo Station, Antarctica. Operation Deep Freeze 1964 (Photo PH2 D.C. Armstrong). Courtesy of the US National Archives, College Park, MD, accessed March 2012.

men begin to live comfortably, the faster the rest of the work would go' (Wilson 1956: 109).

This is good advice in any setting, but it becomes even more urgent under extreme circumstances such as extremely cold temperatures.

The earliest structures built by the USN on Ross Island were metal Quonset and panelised huts. Like early historic huts, they were prefabricated and designed to be easily transported and assembled. Designed for military defence forces working in different climates, these buildings were also easily modified to specific site conditions or needs of the programme. Quonset huts in particular were well suited to the demanding weather conditions in the Antarctic provided they could be fitted with extra insulation; at the end of WWII and the Korean War (1950-1953) there was a surplus of these structures. Soon to follow was another type of hut, a boxy structure known as a T5, an Arctic prefabricated panelised wood hut. It arrived in palletised modules and could be assembled quickly and customised. These types of structures made up the majority of the station's first buildings.

The Quonset hut, an icon of 'portable architecture', was born out of the need for easy, quick housing for soldiers during WWII (Fig. 9). Named for its original place of construction (Quonset Point, Maryland), the Quonset hut was designed and built by George A. Fuller and Company. It not only provided soldiers with a dry, comfortable shelter, but one that could be easily 


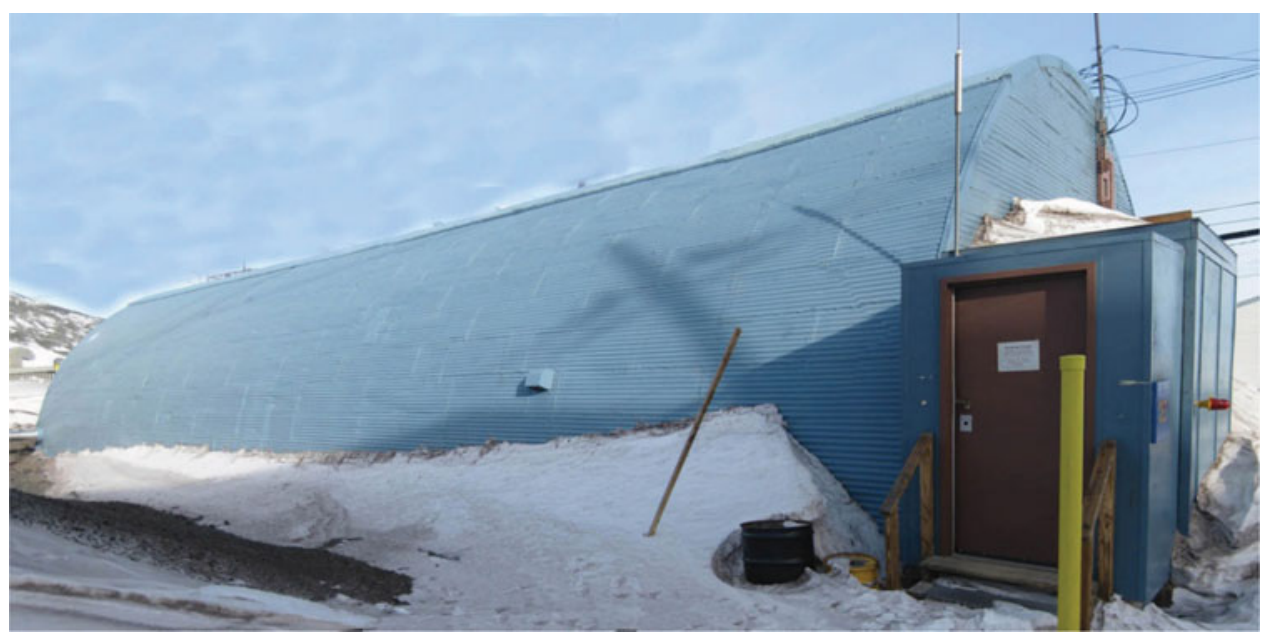

Fig. 9. A Quonset hut in McMurdo Station with a vestibule entrance addition. Photo by author, 2009.

constructed or dismantled by ten unskilled men in one day and could be adapted to different climates (for example, by adding a vestibule). Basing their design on the British Nissen hut from WWI, the designers, architect Otto Brandenberger and engineer Peter Dejong, vastly improved on the design, making it lighter, easier to assemble and much more comfortable. Different people over the years contributed to its improvement, making it even lighter, simpler and more watertight. The original Quonset hut used paper insulation between metal panels and a thin layer of Masonite mounted to wooden secondary beams, called purlins. This, along with a wooden platform floor, was an improvement over the Nissen hut, which used only an air space for insulation, generally rested on exposed ground, were complicated to assemble and required many small parts. Because of the war effort, the design, construction and improvements to the Quonset hut occurred quickly, with the first design shipped merely two months after the commission. The Quonset hut proved easy to modify with changes applied quickly on the factory floor.

However, one early complaint with the Quonset hut was the wasted space from the curved walls. Within a year of the initial design, Brandenberger modified the curved walls to increase efficiency. This time, the arch (now two sections instead of three) rested on a $1.2 \mathrm{~m}$ vertical wall, providing more usable space. He made the overall system lighter as well. Shortly thereafter the design was altered by the Stran-Steel Division of the Great Lakes Steel Corporation, when it took over major production from the factory at Quonset Point. They removed the vertical walls, expanded the footprint, and created a new framing system that eliminated the need for bolts (Decker and Chiei 2005). It also relied more on stock metal that did not need to be modified in a factory. This helped alleviate the demand for steel, which was in short supply during the war.

A special type of Quonset hut known as the Jamesway (created by the James Manufacturing Company of Fort Atkins, Wisconsin) was a hybrid structure with features of both a fabric tent and a metal Quonset hut (Fig. 10). It was a multipurpose building, sometimes acting as a bunkhouse. The Jamesway had wooden ribs covered by an insulated fabric, which lowered demand for steel. Similar to a Quonset hut, a Jamesway could be built to whatever length was needed, the limiting factor in the cold desert conditions of Antarctica being fire safety precautions and logistical mobility (Sherwood 1965). ${ }^{4}$ It was lightweight $(544 \mathrm{~kg}$ ) and easy for the Army Air Corps to transport and use in polar conditions. With few metal components and little need for work that required the removal of mittens or gloves, it was easy to erect. The covering was also fire resistant and vermin proof (very important in the Antarctic). A bonus came with the fact that the packing crates doubled as the floor (Decker and Chiei 2005: 149). Performing best as a temporary shelter, there are few Jamesways left in McMurdo; however, they have been used for decades in field camps.

Similar to the Quonset hut, the plain, boxy T-5 hut was easy to transport, erect and modify for different purposes. In Antarctica, the T-5 served as a quick, no-frills building that could be assembled by a handful of men with only a few common tools: three hammers, three screwdrivers, one wrench, a $30 \mathrm{~m}$ measuring tape and a level. The structural system was $1.22 \times 2.44 \mathrm{~m}$ plywood insulated panels and steel or timber roof trusses, which meant that the structure required no load-bearing interior walls and was thus very flexible. It also meant that interior walls could be quickly and cheaply made of plywood or even simply a drawn curtain (NRC 1957: 36). These buildings generally had a snow load capacity of $244 \mathrm{~kg} \mathrm{~m}^{-2}$ and a wind load of $100 \mathrm{mph}$ (Sherwood 1964a: 3).

The T-5, designated as a standard design in 1955, was a $6.10 \mathrm{~m}$ wide by $14.60 \mathrm{~m}$ long structure that could be tailored to specific needs (that is, a different module size). It was relatively lightweight and transportable on an LC-130 aircraft. The wall panels weighed $45 \mathrm{~kg}$ and came in three types: plain, window and door. These were interchangeable, allowing extra flexibility with layout 


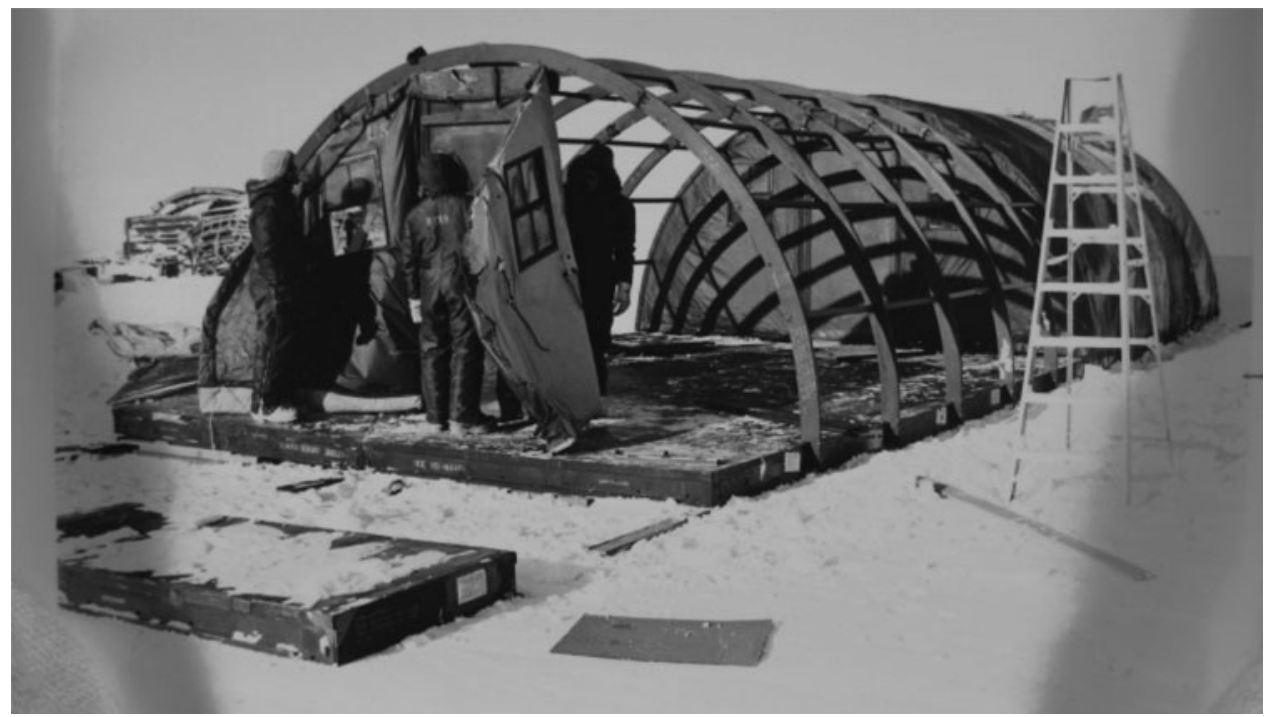

Fig. 10. Byrd Surface Camp, Antarctica. Jamesway tent under construction during the Deep Freeze 1980 season. (Note the flooring.) Photographer: Jeff Hilton. Date: Nov. 6, 1979. Naval Photographic Center, Naval District, Washington, D.C. Official U.S. Navy Photograph.

and window location (Fig. 11). There were also floor and roof panels. Its designation as an 'Arctic' building stems from its purpose to provide '... comfortable living conditions in ambient temperatures as low at $-54^{\circ} \mathrm{C}^{\prime}$ (US Department of the Army 1957: 3). The entire building was sealed with a 'surface mounted wedge clip' (see Sherwood 1964b: 8) which '... provided maximum rigidity with minimum heat loss ...', at least at the joint connections (NRC 1957: 36).

The interior of the T-5 was generally long and rectangular, with small, square windows about $163 \mathrm{~cm}$ above floor level. There was no built-in daylight control (many of these structures ended up in the subnivean tunnels of stations located on an ice shelf). Windows were fixed and comprised of two triple-glazed $0.32 \mathrm{~cm}$ plastic plates that were sandwiched between another $0.16 \mathrm{~cm}$ layer of plastic. Wall panels had a 'stressed cover', consisting of $0.64 \mathrm{~cm}$ thick exterior grade plywood glued to a frame and lined on the inside (the warm side) with aluminium foil on Kraft paper, extending up the side of the frame to form a cup, which was then filled with fibreglass insulation (US Department of the Army 1957: 6). Floor panels were similar but made of slightly thicker plywood (weighing 59 $\mathrm{kg}$ per panel). All interior surfaces and walls were covered in '... attractive fire-resistant paint' (NRC 1957: 36).

Heat usually came from a $20.5 \mathrm{~kW} / \mathrm{h}$ military model, fully assembled space heater. There was a roof jack and a special roof panel for it to vent. Additionally, below each window there were small slots, regulated with rotary covers, intended to help with the ventilation of the building. This building type was probably not intended to stay in service for over 50 years, but in McMurdo a few of them have. One of the first buildings on Ross Island (besides Scott's Discovery hut) was a T-5 Arctic panelised building (Dufek 1957). Its fate is unknown, but
Building 78, a T-5 building from 1960 , is still actively used. ${ }^{5}$ The T-5 Arctic hut served well as an easy-totransport, easy-to-erect building, well insulated and very adaptable. With partitions it could be converted into a dormitory, recreational area, hospital, office, movie room, galley, whatever was needed; that is the beauty of the convertible (that is, flexible) building.

Performance studies conducted on these buildings by the NCEL (for example, Sherwood 1964a; Hoffman 1974) indicate the USN's concern for the Antarctic mission but relative lack of experience in extremely cold climates (compared with countries such as Norway and Russia). The report begins by stating that:

'[c]omfortable living conditions in polar regions are essential for high morale and consequent productiveness of a work force' (Sherwood 1964a: 1).

In the rest of the report the implication for these modular, well-insulated buildings was that they would also be economical and energy efficient, but the fact that occupant comfort is mentioned so prominently at the beginning may indicate an awareness of how it affects productivity and health, especially in such cold, confined conditions.

A further study in 1964 led to modifications to the T5 to make it more comfortable as a barracks. Changes included better noise control, more single-occupancy bedrooms, higher ceilings and larger, double-occupancy rooms. There were also improvements to the construction and assembly of the structure (Sherwood 1964b). The result was a modified and improved T-5 structure, a:

'... prefabricated, straight-sided, frameless wooden building with load-bearing walls and a 1:10 gable roof supported on trusses' (Sherwood 1964b).

Its basic length was $17 \mathrm{~m}$, but as usual it could be adjusted in $1.2 \mathrm{~m}$ increments. The floor was also slightly 


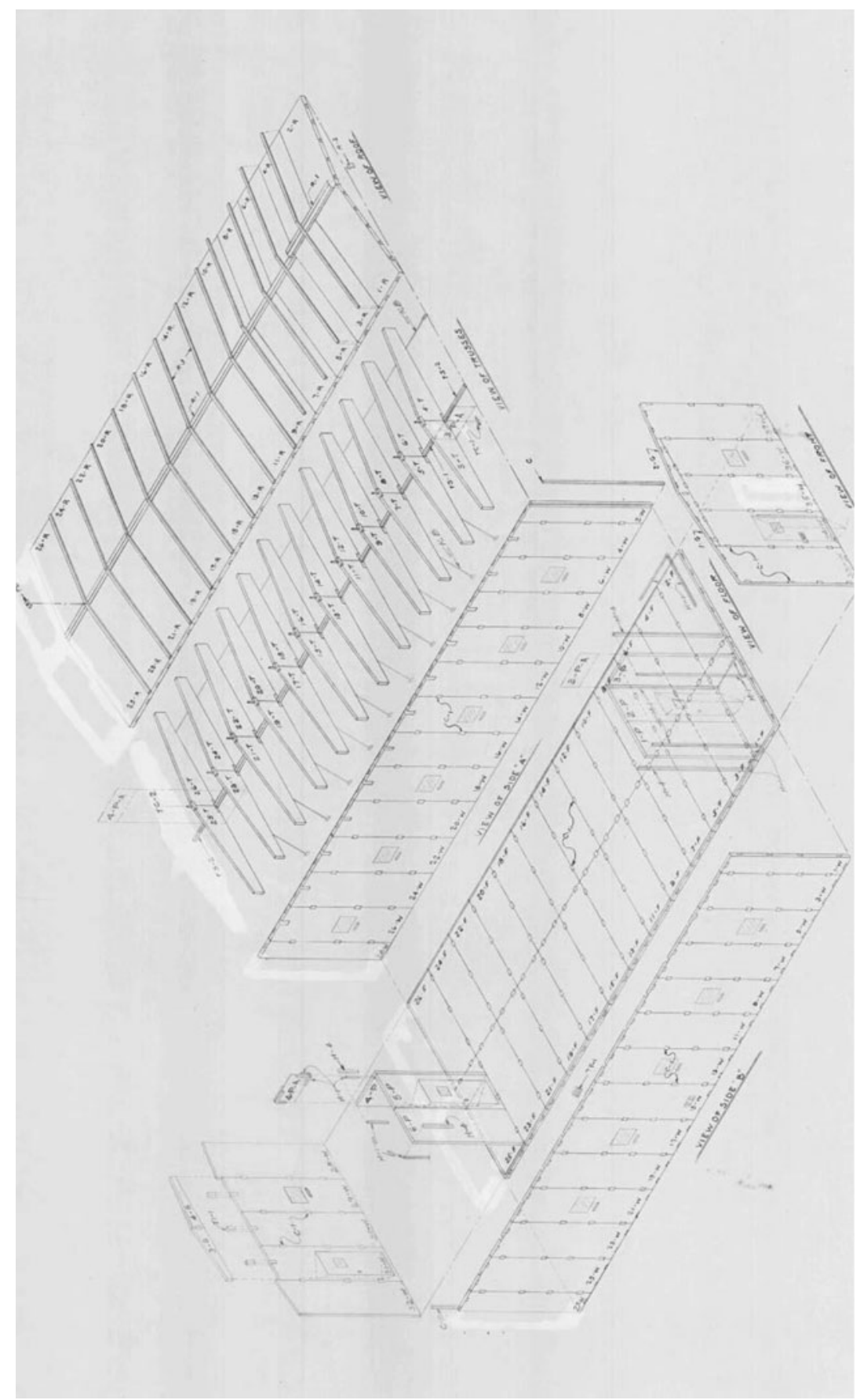

Fig. 11. An Arctic T-5 building, a prefabricated, panelised, wood structure. McMurdo Sound Air Facilities (Avionics Shop, 1961) $20^{\prime} \times 52^{\prime} \times 12^{\prime}$ assembly diagram. Courtesy of the National Archives in College Park, MD, accessed March 2012.

thicker because it used a thicker layer of plywood. The entire kit weighed $14,387 \mathrm{~kg}$ as shipped and could be transported by plane.

Successfully tested in Barrow, Alaska, the T-5 and modified T-5 proved their ability in the field and were used extensively in the early years in McMurdo. However, as the mission (Operation Deep Freeze) became more focused on long-term occupation (that is, continuing political presence, scientific research and logistical support for South Pole Station), the use of new T-5 structures ceased and they were replaced with a steel-frame version, a structure and siding system known as Robertson Buildings (Fig. 12).

Robertson buildings are a:

'... steel clad three-inch insulated panel without any metal fasteners extending through it ... [with a] coatedsteel vapor-barrier at its interior side [to prevent] moisture penetration' (Hoffman 1974: 5-1). 


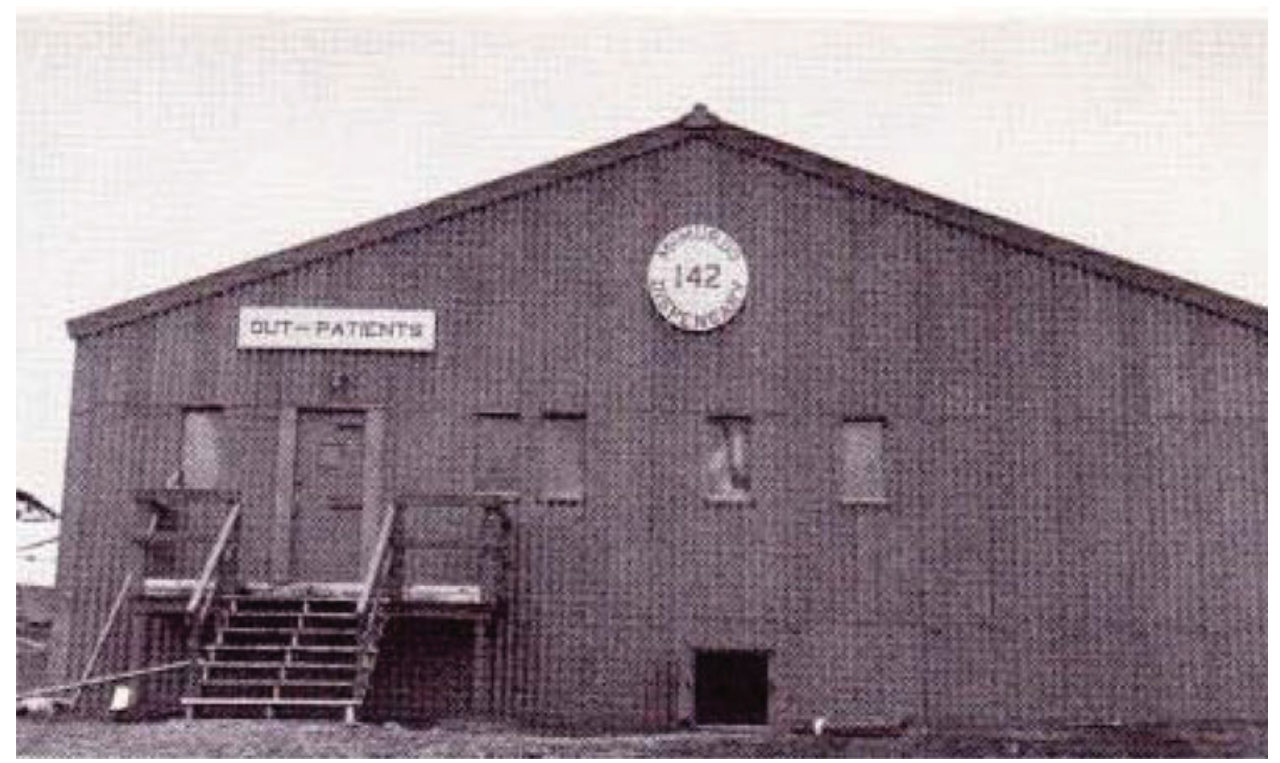

Fig. 12. The medical dispensary around 1968, an example of a Robertson Building. The front door has changed, but this building has stood since 1961 (USN 1968: 36).

They are just as unremarkable in appearance as the T-5 designs but were better insulated and, as was mentioned, more flexible when it came to the customisation of the interior design, as was needed for the increasingly wide range of activities occurring at the station. Crucially, they were still easy to assemble and were built from prefabricated parts both for the steel skeleton and the insulating panel siding.

Manufactured by the H.H. Robertson Company of Pittsburgh, Pennsylvania, this type of building can still be seen today, either as relics of the past (for example, the medical building) or as updated versions of newer buildings (for example, the three-storey dormitories). In the 1974 NCEL Engineering manual, the building system is described as thus:

'The panel used at McMurdo Station [was] the H-

Type Q-Panel, [which was] insulated with 3 inches of fiberglass and contain[ed] no metal fasteners [that extended] through the panel. A coated-steel vapor-barrier on the interior side prevent[ed] moisture penetration.

[The manufacturer] stat[ed] that at $-50^{\circ} \mathrm{F}$ outside and $70^{\circ} \mathrm{F}$ inside, condensation should not form even with a relative humidity of 80\%" (Hoffman 1974: 5-1).

It should be noted that the insulation used was galbestos, a product also manufactured by the H.H. Robertson Company.

'Galbestos panels consist of two metal sheets with an intervening layer of insulating fiber glass. The trade name derives from the treatment of the metal surfaces, which by a special process are galvanized and impregnated with asbestos fibers' (Barber 1968: 140).

So popular was the Robertson Building that the NCEL manual notes that only two buildings being replaced or built at the time were not of this design: an old aircraft hangar and the $\mathrm{USARP}^{6}$ administration building (the future NSF Chalet), with its wood structure chosen for its '... more pleasing architectural style' (Hoffman 1974: 5-1). Today the remaining Robertson buildings are used as warehouses and are showing their age, with the exception of the three-storey dormitories, which were built in the late 1980s with a more modern, asbestos-free siding system.

Although some people still have an affinity for the distinctive shape of the Quonset hut today, the earliest buildings used in McMurdo Station were made neither to last nor to leave a lasting impression. Their exteriors are unremarkable to those unfamiliar with their history. Their mission was to provide a heated shelter for the men participating in Operation Deep Freeze, and be easy to transport, erect and disassemble. Today we characterise these structures as drafty, crowded and offering little or no privacy, but at the time they served their purpose well. With the success of the first IGY, the US decided to extend its Antarctic mission beyond 1959 and replace the temporary facility at McMurdo with a more permanent one (Hoffman 1974: 2). Prior to this decision there were few facilities for conducting scientific research at NAF McMurdo, which mostly served as a base for aircraft servicing other stations or nearby field camps. In 1959 a small biology laboratory appeared (the McMurdo biological laboratory, later renamed the Eklund Biological Center).

After a few years it became clear that the station needed a plan for its upkeep and expansion. To accomplish this, the USN ordered the NCEL to create a long-range development plan (LRDP) so that the current, short-term facility would be able to aid scientific efforts on-site and at remote stations, mainly the new station at the South 
Pole. It was the first of several subsequent LRDPs for the station.

\section{Transition to the NSF (1961-1979)}

By 1961 most nations had begun to scale back their activities on the continent. In contrast, this was the beginning of a period of growth for the recently renamed NAF McMurdo Sound (Collis and Stevens 2004: 4). In 1961 the USN issued a plan for the station titled Preliminary study for reconstruction and improvement of U.S. naval air facility, McMurdo, Antarctica. According to the document, the station would grow to 58 buildings, accommodating up to 1,500 people in the summer and 500 in winter; it would be large but compact, with facilities close to those with related functions, and would include a central, all-purpose building in the centre and buildings for various scientific fields (DMJM 2003: 3-4; Klein and others 2008). The addition of a nuclear power plant in 1962 helped provide power and potable water for the growing population. Unfortunately, Klein and others (2008) note that with the exception of a station core building and a few warehouses, most recommendations in the 1962 plan did not come to pass.

Around 1969, the first large building constructed, the steel-framed, $6,316 \mathrm{~m}^{2}$ station core facility practically named 'Building 155' dominated the centre of the station, replacing several smaller structures and providing access to food, housing and recreation in one building (Fig. 13). It maintained the line of the two main streets but also changed the dynamics of the layout, with its large mass creating a barrier in the middle of the station. With or without the guidance of a LRDP, McMurdo Station had grown in scope and scale. At this time there was still a distinct military feel to the station despite a growing scientific programme. Officers and enlisted men, along with scientists, still ate in segregated areas in the 'galley', purchased snacks in the 'Ship's store', and slept on the second 'deck' of Building 155. Terms like this still decorate the lexicon of the station, and in a way even today it feels like McMurdo is still transitioning from its historic naval roots. Here, change often comes slowly.

While most accounts list the year 1972 as the time when control of the station was handed over to the NSF, it was actually a series of events spanning several decades, not a single point in time. There is no clearcut date for the handover; the transition away from the military leading the way and supporting the scientists was not officially completed until 1998, and today there are still Air National Guard pilots who fly LC-130s and the Airforce flies C-17s on and off of the continent. The reason for the shift away from the Department of Defense (DOD) involvement appears to have been monetary. Each new private contractor has since taken on more responsibilities, including logistics, planning, hiring and the development of LDRPs. For these reasons, there is little evidence of a dramatic change in the way architectural, engineering or planning projects were handled at McMurdo Station in 1972.
As early as 1960, according to the NSF, the Bureau of the Budget (now the Office of Management and Budget, OMB) released a directive known as 'Circular A-51, Planning and conduct of the United States program for Antarctica', granting the NSF power to:

'...continue to exercise the principal coordinating and management role in the development and carrying out of an integrated U.S. scientific program for Antarctica' (NSF 1996).

Major logistical operations at the stations were still handled by the DOD.

During this period, scientists at McMurdo Station lived and worked in the company of service personnel. All support, ground transportation, medical services, search and rescue (SAR) and accommodation were provided by the USN. The barracks, galley and clubs were still segregated by rank, although scientists moved freely among these places. Then in the late 1960s the USN and NSF began to explore the idea of shifting the support role to private contractors. In 1968, the first private contractor, Holmes and Narver (H\&N) (a subsidiary of Ashland Oil Company), was hired to help oversee the station. The first project they undertook in McMurdo was the erection of the NSF 'Chalet', the official NSF building at the station (Fig. 14).

A 1970 memorandum reviewed by President Richard Nixon and signed by Secretary of State Henry Kissinger directed the NSF to continue its active presence in the Antarctic as stated in the 1960 A-51 Circular, but also to begin (officially), a transfer of the responsibilities of the Antarctic programme from the DOD to the NSF. These responsibilities included the continued use of government agencies for logistical support where a mutual agreement could be reached, but also the use of commercial (private) support when cost-effective on a 'mutually acceptable reimbursement or nonreimbursement basis' (NSF 1996: 2; National Security Council 1970: 2). These changes were ordered to be finalised by 1972. The memorandum put the NSF in charge of the programme, and it was up to the NSF to decide whether to use government logistical support or look towards private contractors. As it turned out, working with the private sector was much more costeffective.

For several years after the NSF took over, much support was still provided by the USN although there was an increased reliance on private contractors. It was the NCEL, not H\&N, that in 1974 released an engineering manual for McMurdo Station (see also Easton 1969). The manual was intended to serve as a record of information gathered from years of research and experience which the USN had acquired. It described:

'.. the terrain and environmental features in the vicinity of McMurdo Station ... and present[ed] engineering methods and operational procedures for working within these natural constraints' (Hoffman 1974: 1).

The manual included information on subjects ranging from working and building on the ice shelf to the properties 

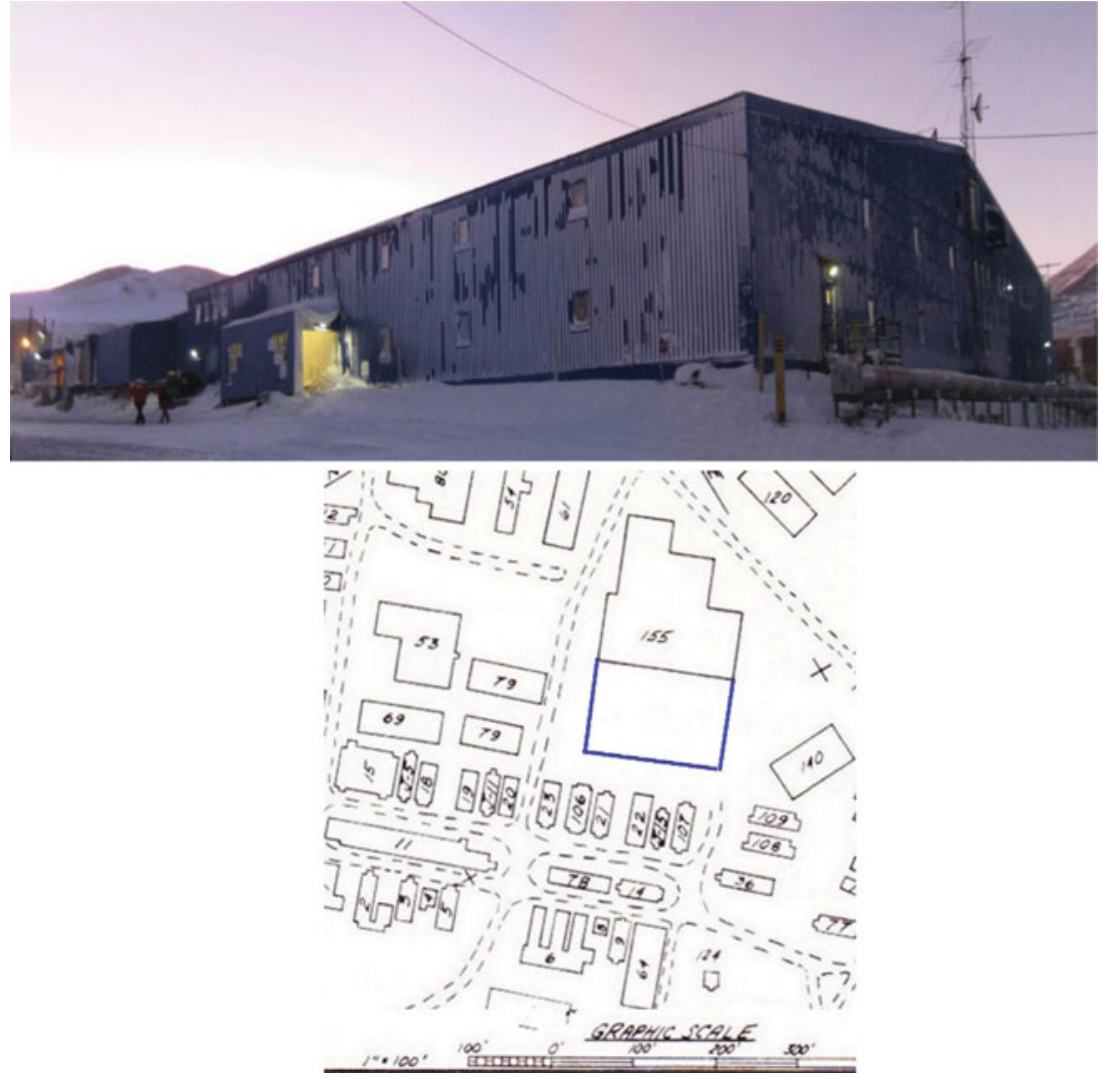

Fig. 13. (Top) Building 155, now painted blue, after a wind event, August 2010. Photo by author, 2010. (Bottom) Layout of Station around 1968 showing a halfbuilt Building 155 (blue lines, added by author, show final extent) (USN 1968: 24).

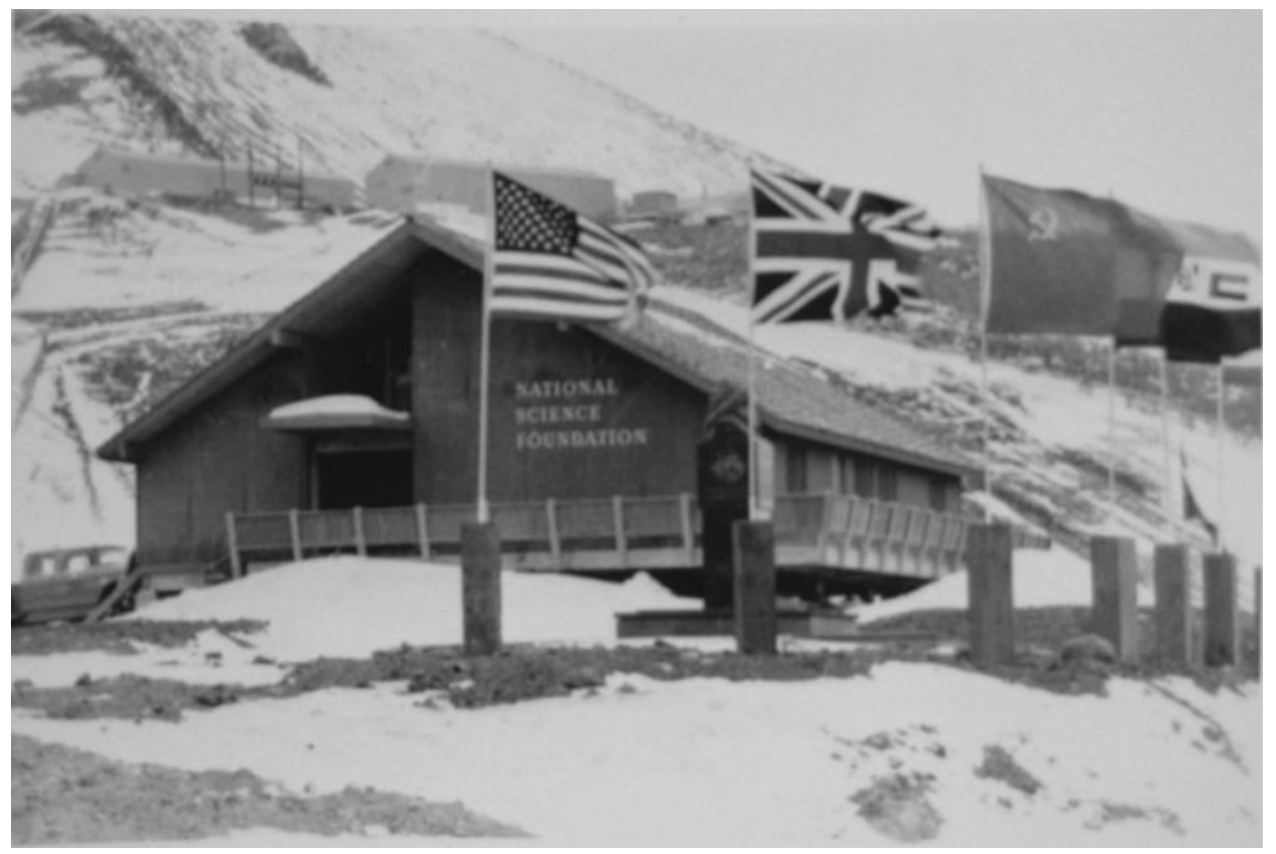

Fig. 14. The NSF chalet in November 1972 (Photo PH2 David M. Dyer). Courtesy of the US National Archives, College Park, MD. 
of snow and permafrost, to the design and maintenance of station buildings. There are even results of the NCEL report on Portland cement in Antarctica. Also included was a brief history of the founding of the Naval Air Facility and its new designation as a permanent Antarctic station. This was not, however, a master plan. As the firm that later designed the science lab for McMurdo wrote:

'[A]lthough technically successful in its purpose to establish a building standard for the station, the manual was not intended to address a comprehensive plan for the station's development. The functional needs of the building inhabitants, infrastructure, and esthetics were given a low priority, as can be seen in the expanding chaotic collection of metal building forms connected by elevated utility lines and pipes that finally resulted from the implementation of the manual in the absence of a station master plan' (Ferraro 2010: Ch. 7).

It was instead a record of hard-won knowledge about building and working in McMurdo Station and served as documentation of the often complex chain of events that led to the station's current state.

Pushing the station towards a more permanent presence, it also recommended a transition to a metal version of the T-5 (that is, the Robertson Building), which also allowed greater variation in the interior designs than the previous T-5 model. By 1968 they were considered the 'principal Antarctic structure, [having] been used to satisfy a wide variety of needs' (USN 1968: 36). The dormitory that came to be known as Hotel California (1968) was steel-framed with insulated metal siding and roofing, steel-framed heavy-timber floors and woodframed gypsum board interior partitions. At the time of its construction, this building was considered an upgrade from the Jamesways that often served as housing, and it was another example of how the change to metal buildings was another step towards making the station more permanent.

The 1974 NCEL report changed the face of McMurdo Station; however, as it was an engineering proposal and not a long-term comprehensive plan for a scientific community, the station continued to operate but did not age well. As one of the architects who designed the Crary Science Laboratory later noted:

[t]he station's complexion became an affront to the serene beauty of the Antarctic and an embarrassment to the United States when the news media began to report on the status of the continent's environment' (Ferraro 2010: Ch. 7).

So despite its growth, McMurdo Station was still being treated like a collection of buildings. There was a need to look at the station as a whole and create a LRDP that also took into account the design and evaluation of the buildings not only from an engineering standpoint but from a more comprehensive architectural one: energy efficiency alongside human comfort, design and productivity.

\section{McMurdo Station: 1979-present}

It was not until 1979, near the end of their 12-year contract, that $\mathrm{H} \& \mathrm{~N}$ released a master plan, the Long range development plan, Antarctica, which focused on replacing existing small, temporary structures in McMurdo with larger, more efficient ones and consolidating buildings in already developed areas (DMJM 2003). Under this plan, changes to the station could be implemented over the course of ten years or more.

New buildings would include for the first time both attention to utility connections and personal privacy. With the backing of the NSF, science facilities, badly in need of renovation, were improved as well (Ferraro 2010: Ch. 8 ). Additionally, the main power and water plants were moved from a location on Observation Hill to locations closer to the ocean, although it is not clear why. There has been some discussion of a gravity-feed system that takes advantage of natural topography would improve reliability of water delivery for fire suppression systems (Augustine and others 2012: 214), but current systems rely solely on pumps. According to Klein and others:

'[S]tation development since 1979 has generally followed this long-range plan (Klein and others 2008: 16).

Yet, the reality remains that while a few facilities were consolidated according to the LRDP, the organic layout persisted and was reinforced through the improved definition of existing circulation routes (DMJM 2003: 3-4). However, the move away from a military-style station towards one focused on science was clear, and it was soon reflected in the types of buildings constructed (more permanent) and how funds were distributed (biased towards science efforts instead of maintenance). Slowly, the rigid lines of the old naval station blurred. The fading visibility of the military plan:

'[A]lso points to the demilitarization of the US Antarctic presence: McMurdo was initially constructed as a Naval Air Facility, but in a continent in which science rather than military might guarantees territorial influence, the station's military foundations, as well as its contentious use of military personnel in Antarctica, are increasingly downplayed' (Collis and Stevens 2004: 246).

It is not clear whether subsequent contract holders acted on a mandate from the NSF or independently to publish master plans, but nearly all produced ambitious plans or updates for McMurdo Station. However, lack of a comprehensive budget repeatedly undercut all these proposals. Over the next 10-20 years McMurdo developed as needs arose and budgets allowed. The layout gradually moved away from a grid and towards a more organic layout based on the topography of the site, although overall the patch of ground that is today's station has been graded extensively (Planning for tomorrow 1993: 4). Buildings sites were chosen where it was convenient, or wherever a patch of relatively flat ground could be created (DMJM 2003: 3-4). Natural features, a steep slope towards the 
coast and the icy craters on all other sides, seem to be the only barriers to expansion.

Even today, US stations in Antarctica are not budgeted all at once, but as needed. Unfortunately, the budgets rarely include funds for maintenance. Rather, buildings and stations must make do until a lack of maintenance impedes scientific endeavours. Only then are improvements funded. New buildings are generally built one at a time and years apart. In one rare instance, the new South Pole Station was completely replaced with one massive Congressional appropriation. This is not the norm and at McMurdo it has not happened since the original IGY and subsequent decision to make the station permanent.

After $\mathrm{H} \& \mathrm{~N}$ the next contract was awarded to ITT Antarctic Services (based in New Jersey) from 19801990. During this time, McMurdo underwent a number of new construction projects, including a new power plant (which housed diesel generators), a replacement to the vehicle maintenance facility (VMF) that was destroyed by fire, and four three-storey dormitories (Buildings 206209). No documents from this contractor could be found, so it is unclear which buildings (if any) were designed by ITT and which were projects slated for construction before ITT assumed the contract.

Between 1990 and 2000, Antarctic Support Associates (ASA), a joint venture between H\&N and EG\&G (known as a US defence contractor), held the Antarctic contract. It was during this time that the USN formally pulled out of the Antarctic. In 1993, after 42 years serving the US Antarctic Program (USAP), it announced its decision to withdraw. On 20 February 1998, a ceremony in Christchurch, New Zealand, commemorated the official end (although the USN still provided some flight support until the end of the 1998-1999 season) (NSF 1998).

By this time the role of the contractors had increased. Along with the NSF, ASA oversaw the completion of several projects, some of which had been outlined in the 1979 LRDP (for example, new dormitory facilities), and most prominently, the new science laboratory - the scientific heart of the station - the Crary Science and Engineering Center (1987-1993). In 1995 ASA released an update to the H\&N LRDP. Known simply as the 1995 Update to the $L R D P$, this report re-emphasised consolidation, functionality, footprint reduction and replacing inefficient older structures. It is considered more of a facilities replacement plan than a 'city development plan' (OPP 2003: 2). Considering the way Antarctic infrastructure projects are funded, it could be considered a pragmatic approach.

Raytheon Polar Services took over the Antarctic contract in 2000. In 2003, it issued its own update to the LRDP, a report compiled by DMJM. ${ }^{7}$ This document covers land use, facilities development, utilities development, site development, vehicle and pedestrian circulation, and design controls. Aside from being the only easily accessible LRDP document, it appears to take into consideration comfort and 'human factors' more than any previous proposal, and it includes what might be the first serious discussion of the need for improved energy efficiency. While paying the most attention to building upgrades and energy saving measures, the authors of the document attempted to create guidelines for new buildings, including more single-room dormitories. The authors explicitly state that:

'... energy wastefulness impacts comfort levels and operating costs' (DMJM 2003: 3-24).

Phrases such as 'productivity and spirit of community' and 'quality of life' were used in an assessment of current conditions at the station. The DMJM authors list several other observations made during their initial site visit that are unusual for this type of document, including:

'(1) McMurdo's 'remote outpost' feel combines 'aspects of a mining town, military base, and college campus';

(2) Although it is a remote, old USN base, it is still a community of science and support people, and there are ways to improve the feel and wayfinding systems on the station;

(3) Logistics are the 'life blood' of the station and it is imperative to provide for the people that make this possible;

(4) The station has developed in an inefficient and haphazard manner;

(5) Many of the buildings are some of the original ones from the 1950s and 1960s; and

(6) In part because of the aging buildings but also because they require excessive travel between them, the station is not energy efficient' (DMJM 2003: 1-2).

These observations are more architectural than in any previous report.

The same year as the release of the DMJM document, OPP released a housing report (OPP 2003) also emphasising human comfort as essential to the future success of the station. The report was a response to 'a request contained in the House Committee on Appropriations Report 1-7-740 accompanying the FY 2003 Appropriations Bill for Veterans Affairs and Housing and Urban Development, and Independent Agencies' regarding the upgrade of housing facilities at McMurdo Station, Antarctica (OPP 2003). Identified in the report as one of the highest housing priorities is a $40 \%$ increase in single-occupancy rooms, highlighting the importance of privacy for everyone working at the station. The presumed increase in site footprint and the cost of providing more private rooms has so far been a barrier for this goal. In 2012, a new push for the actual realisation of these dormitory facilities was proposed, although it appears these plans involve a reconfiguration of existing rooms, not a series of new buildings.

Additionally, Raytheon oversaw an energy study conducted by RSA Engineering, Anchorage, Alaska, in 2008 (RSA 2008) (issued just before the first stages of the Ross Island Wind Energy Farm). It proposed to reduce overall energy consumption and improve employee living and working conditions (RSA 2008). Many of their recommendations address the building envelope, 


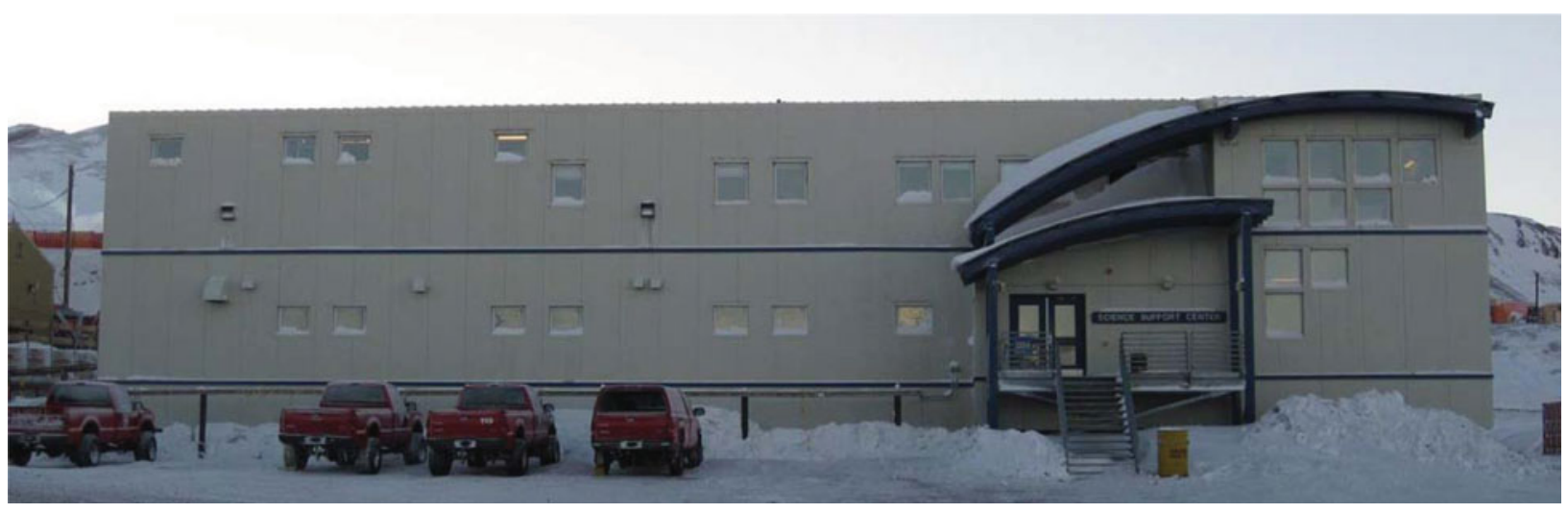

Fig. 15. The Science Support Center (SSC) built in 2004 (Photo by author, 2009).

including improved windows. The report stated that while all federally funded buildings must comply with standards that reference the ASHRAE Standard 90.1-2004 and the IECC-2004/2006, existing buildings in McMurdo will not be able to meet these requirements; rather, the RSA recommendations employ the standards only as a 'reference when providing wholesale retrofits in lighting, thermal or plumbing systems of buildings' (RSA 2008: 7). Since new buildings are not prescribed, there is no mention of actually meeting these standards for an entire building.

The RSA recommendations included: 1) adding new, insulated metal panels to the walls and roofs of pre1973 buildings to reduce heat loss at much as 70\%; 2) installing new vinyl windows to reduce heat loss, improve daylighting and provide additional escape routes; 3 ) installing Solatube lighting systems for reduced dependence on artificial light in certain buildings; and 4) replacing old wooden doors with insulated steel doors with relites to improve the building envelope and to provide a little extra daylighting.

In effect, the 2008 study was not a LRDP, but a list of short- and long-term projects aimed at reducing fuel and water consumption. It was possibly commissioned because of an increasingly volatile energy market. A few projects in the report were completed, such as the new generator building and the improved heat trace system (to keep fluids in pipes above ground from freezing). The proposed integration of the Scott Base wind turbines, completed in 2010 , is now a reality.

Today the buildings in McMurdo Station have not changed radically in appearance; that is, despite several building types there is no visual focal point, and no building that does not fall into the 'mining town' aesthetic. Projects are generally funded one at a time, so the few modern buildings (built within the last 20 years) are outweighed by dozens of older buildings.

The newest arrival at the station is the $3,716 \mathrm{~m}^{2}$ Science Support Center (SSC) (Fig. 15). An Arctic entry below a distinctive porch covering leads into a double-height lobby with many windows providing daylight into the main staircase. A front office, walled-off from the lobby behind a large window, also benefits from some of this daylight. The L-shape of the SSC affords more access to windows throughout the building. In addition, the building has solid floors made from concrete slabs resting on a steel frame (off the ground). Form-wise, it may seem like an unremarkable building but, if compared with the limitations of a Quonset or T-5 hut from the 1950s, it demonstrates how much construction and engineering techniques have evolved and how design issues, once thought to be details or luxuries, are now receiving more attention.

\section{Future of the station}

Expanding one's scope, it is possible to find innovation and inspiration from non-US Antarctic bases, ${ }^{8}$ as well as from other US reports on facilities located in extremely cold regions. These designs and ideas could be adapted for McMurdo, even though it is larger than all other Antarctic bases and is no longer a military-run station. For instance, in their document called the Unified facilities criteria (UFC) for Arctic and sub-Arctic buildings, the DOD considered (among other things) the differences between multiple versus composite-building concepts for military buildings.

First, noting that multi-building stations are often the result of remote sites, the UFC document points out that these more organic layouts suffer from large physical footprints (including extensive heat and power distribution infrastructure) and high heat loss from multiple exterior walls and roofs, which necessitate large capacity heating systems. However, these losses may be deemed acceptable if one considers adaptability and fire safety to be a high priority. Multi-building stations can be flexible when it comes to building on uneven terrain and in terms of heating, ventilation and air conditioning (HVAC) systems (if there are small structures that do not require mechanical ventilation); smaller buildings also do not require complex foundations. Additionally, the authors of the document add that:

'[i]n cold weather there are psychological advantages in being able to get away from living and working 
areas by walking in the covered passageways' (DOD 2004: 1-1).

However, the authors of the UFC document also acknowledge that composite-building stations have their advantages such as: 1) a lower surface-to-volume ratio (lower heating demand), 2) lower construction costs (fewer roofs and foundations) and 3) easier maintenance. Composite structures also benefit from centralised heating (fewer distribution lines) and amplified savings for multistorey buildings. On the downside, there is a great risk from fire spreading (so greater protection is required) and less flexibility when it comes to standardised building systems. The authors of the document recommend moving noisy, odorous activities (for example, diesel power supply) to a separate structure for the sake of health and morale of the station occupants. Although the authors of this document recommend the compositebuilding approach, they also indicate that it is best for remote and small installations. McMurdo Station outgrew this label decades ago.

Lockheed Martin (now Leidos) currently holds the civilian support contract for McMurdo Station, and it is continuing the tradition of issuing a station report. In 2013, Lockheed commissioned an architectural firm to create a new plan, to guide (or completely reorganise) the station over the coming decades. The proposed master plan builds on the extensive 2012 report, issued by the USAP Blue Ribbon Panel, about the future science and logistics plans for all of the US Antarctica stations. The authors of the 2012 report observed that, despite science being the main reason for maintaining a presence in the Antarctic, the supportive logistical effort requires nearly nine times the amount of time and money; the report likened the 1:9 ratio to that of the mass of an iceberg below and above water. The panel noted that:

'US activities in Antarctica are very well managed but suffer from an aging infrastructure, lack of a capital budget, and the effects of operating in an extremely unforgiving environment' (Augustine and others 2012: 7).

In McMurdo these problems are highly visible, ranging from old, drafty buildings to scattered and nearly derelict warehouses, to an outdated inventory system. Therefore, it may not be a surprise that the architectural firm's proposal, rather than once again recommending small fixes, instead recommends replacing nearly every building in McMurdo over the course of several years.

As the title of the 2012 report, More and better science in Antarctica through increased logistical effectiveness, indicated, the members of the panel found that the majority of problems, including both the overall cost and simultaneous ability to accommodate scientists are the result of out-of-date logistics and a crumbling infrastructure; this was often the result of diverted funding going towards science as long as the logistics and infrastructure could survive another season. The report noted that if there is a choice between ' ... repairing a roof or conducting science, science usually prevails' (Augustine and others 2012: 7).
However, at some point this becomes a self-defeating policy.

The panel focused on streamlining logistics and updating parts of all three US Antarctic stations. The goal was to reduce the percentage of the budget spent on support and logistics that would in turn provide more funding for Antarctic science grants. Some improvements included the need to restore the US polar ocean fleet, to decrease the number of LC-130 flights to McMurdo and the Amundsen-Scott Base, and to decrease the contractor personnel by $20 \%$. This might bring McMurdo Station's peak population close to or under 1,000 people.

Regarding McMurdo Station specifically, the panel acknowledged the haphazard arrangement of the station but also concluded that there was no better location (logistically) and that an investment in a new station the size of McMurdo Station located elsewhere would reach \$220-300 million (Augustine and others 2012: 12; Leshner 2016). Rather, improvements to the station could help make up for any of the less-than-optimal conditions. Of the ten main recommendations, three relate directly to architecture and engineering. Naturally, one of these is to increase the energy efficiency of the station and its use of renewable energy, with the panel pushing for more wind turbines, a way to incinerate solid waste and waste oil for extra heat, and improved insulation in several key buildings. The second recommendation focuses on reducing operational costs through an updated master plan of the station as well as an improvement to dormitory facilities (for example, the reduction of the spread of communicable disease in these buildings).

These recommendations are all important because the third recommendation is that the scientific programme is to be continued at the existing station. Although the panel countered this by adding that:

'[D]espite a workforce that takes great initiative in doing what it can with the available resources, [s]imply working harder doing the same things that have been done in the past will not produce efficiencies of the magnitude [needed] in the future; not only must change be introduced into how things are done, but what is being done must also be re-examined' (Augustine and others 2012: 21).

With a new contract holder at the helm of logistical support, this may be an ideal time to do just this: look at the fundamentals of how and what at McMurdo Station, the largest facility on the continent.

Therefore, a sustainable future for McMurdo Station will hinge on the resolution of fundamental problems that have developed over several decades of budgeting challenges and neglect. A number of these problems exist in the realm of architecture and specifically within the intersection of design, energy efficiency, health and comfort. Other nations have proved that smaller scale installations are capable of providing safe, comfortable and energy efficient scientific research stations. McMurdo Station, however, is a different challenge because it is more 
like a town than any of these smaller stations, which tend to have a more intimate feel to them.

It was with these problems and recommendations in mind that the design firm engaged by Lockheed Martin, OZ Architecture of Colorado, proposed a LRDP for McMurdo Station in 2013 that was the latest in the succession of LRDPs from the USN and a list of private contractors. Their initial vision for the station took an old idea - consolidation - to a new extreme, with nearly every function of the station contained in one massive structure. Excluded were the VMF, hospital, the helicopter hangar and dive locker, the generator warehouse, and water and wastewater treatment plants. In this proposal, the NSF Chalet would be transformed into the new coffee house. The new SSC was to be converted into a facility for field staging and cargo handling, possibly replacing the Berg Field Center (BFC) and food warehouse, a Robertson Building and an old two-storey Quonset hut. Finally, all current dormitories would be demolished and rebuilt as appendages on the single large building. A few station buildings would be connected by surface (structured) or elevated (overhead) walkways.

In addition to footprint consolidation and increased energy efficiency, the OZ proposal mentioned several design aspects such as visual clutter, pedestrian safety and an increased use of multipurpose rooms. In this proposal, the look of the station, while not visually distinct, was more modern and presumably more energy efficient. In a radically different approach to station design, multiple buildings are combined into one large complex, separated by fire walls: all recreational, commissary, office and housing functions. This is useful especially during the winter, but massing such a large building carries with it special challenges.

A second version of this LRDP (made public in the spring of 2016) pulled back on this extreme consolidation in favour of a more moderate one. In this new design, the single large central facility is now spread into three interconnected parts but is still connected (and heavily protected with fire walls). These three structures are phased and timed to be constructed around the current Building 155 without interrupting operations. When appropriate, Building 155 will be demolished, leaving a large, open space (apparently a loading dock area). The current three-storey dormitories remain, but are renovated, with two more of the same style added at the north end. (It is not clear how many rooms will be single occupancy.) At least two of these buildings would be connected by elevated walkways to the central facility and each building is connected to each other.

This bold, new LRDP is in its infancy, and its success will hinge on budgets. Convincing the US Congress to provide funding will be essential, just as it was for the new South Pole Station. Although science is the overt mission of McMurdo Station, the strategic presence it gives the US on the continent and the logistical support it provides for access to the interior will undoubtedly be important considerations in securing support as the station enters the
21 st century. The architectural history of the station will, one hopes, guide future design and engineering decisions for the built environment that will make McMurdo more productive and efficient, and contribute to the quality of life for its inhabitants.

\section{Summary}

The wealth of information embedded in the history of the buildings on Ross Island is a valuable resource for those seeking to improve the living and working conditions through the built environment. Unfortunately, until now, a publicly available, single source of architectural information has not existed. Demands on human habitations have grown from those of a few dozen explorers to several hundred scientists and contract employees. During this time the buildings have advanced from imported wooden huts with little or no ventilation control, to imported steel-framed structures with massive HVAC systems. The complexities presented by this station are compounded by its remoteness, size and architectural legacy. Approaching a new, comprehensive design is daunting. Therefore, it is important to be prepared with knowledge of the specific challenges and cold-region best practices (that is, the mechanical and structural demands of a remote cold desert, ways to promote energy efficiency without sacrificing occupant comfort, and the effects of isolated environments on human behaviour). There are many parameters to apply to new developments at McMurdo Station, but they are beyond the scope of this article. ${ }^{9}$ An architectural history of the station is one tool. Understanding and documenting the history of the station's architectural evolution should remain a priority for any current and future plans.

\section{Acknowledgements}

This article was adapted from my doctoral dissertation at Texas A\&M University. I would like to acknowledge Dr Jeff Haberl and other members of my dissertation committee who provided valuable comments and suggestions. This article also benefited from the comments of two anonymous reviewers and Dr R.W. Davis. I would also like to thank the helpful staff in the Cartographic Section at the National Archives at College Park, MA.

\section{Financial support}

This work was supported in part by the L.T. Jordan Fellows Program (2008-2009), the William W. Caudill Research Fellowship (2008-2009), a travel grant from the Texas A\&M University Office of Graduate Studies and assistantships provided by Texas A\&M University.

\section{Notes}

1. Collis, citing the USN's Development Project (19461947), notes that other goals of Operation Highjump included 'training personnel and testing material, 
consolidating and extending US sovereignty over Antarctica areas, investigating possible base sites and extending scientific knowledge in general' and also 'prepar[ing] the US military to fight the Soviet Union in polar conditions'. Specified instructions included 'develop[ing] techniques for establishing and maintaining air bases on the ice, with particular attention to ... later applicability ... [in] Greenland' (Collis and Stevens 2004: 2). Camp Century is the most relevant example of a USN Base in Greenland.

2. In the NRC document, NAF McMurdo Sound is described as 'The Naval Air Facility ... serves primarily as the base of operation for the air-lift to the AmundsenScott South Pole Station and the long-range air supply of Byrd Station. It is used extensively for aircraft maintenance and support and as a communications and meteorological center' (NRC 1957: 3).

3. The site of Little America V, an ice port known as Kainan Bay, was eventually determined to be too unstable to support long-term resupplying. In contrast, the relatively ice-free tip of the peninsula at Hut Point (where Scott's Discovery Hut still stands), boasts a natural harbour (Winter Quarters Bay) and proximity to both a permanent ice shelf and seasonal sea ice thick enough to support large cargo planes (Hoffman 1974: 1).

4. Logistical mobility is a term used to describe the ease with which something can be frequently disassembled and moved easily, something required in snow-drifted field camps.

5. Now an aerobics room (the 'Gerbil Gym'), it was once the 'Acey Deucy', the enlisted men's bar and hangout.

6. USARP became USAP around 1986/1987.

7. DMJM (Daniel, Mann, Johnson \& Mendenhall) Design was a transportation-related engineering firm, acquired in 1984 by Ashland Oil \& Refining Company; of which H\&N was a subsidiary. In 1990, Ashland was reconfigured and AECOM was created, an architectural design and engineering firm that includes DMJM. AECOM worked with British architects on the new Halley VI Station.

8. For more information see Davis, G. 2015. A study of remote, cold regions habitation and design recommendations for new dormitory buildings in McMurdo Station, Antarctica. Unpublished dissertation. College Station: Texas A\&M University.

9. A discussion of how other design parameters could be included can be found in: Davis, G. 2015. A Study of Remote, Cold Regions Habitation and Design Recommendations For New Dormitory Buildings in McMurdo Station, Antarctica. (Doctoral Dissertation). Texas A\&M University, College Station, TX.

\section{References}

Amundsen, R. 1913. The South Pole: an account of the Norwegian Antarctic expedition in the 'Fram', 1910-1912. (Volume 1). (A.G. Chater, Translator). New York: Lee Keedick.

Augustine, N.R., D. Hartill, T. Allen, G. Jugie, C.E. Dorman, L.J. Lanzerotti, H.W. Ducklow, D.J. McNabb, B. Gordon, R.E. Spearing, R.K. Harrison and D.H. Wall. 2012. More and better science in Antarctica through increased logistical effectiveness. Report of the US Antarctic Program Blue Ribbon Panel. Washington: White House Office of Science and Technology Policy and the National Science Foundation.
Barber, D.W. 1968. Construction report Deep Freeze 68. Antarctic Journal of the United States 3 (4): 139-142.

Belanger, D.O. 2006. Deep Freeze: the United States, the International Geophysical Year, and the origins of Antarctica's age of science. Boulder: University Press of Colorado.

Collis, C. and Q. Stevens. 2004. Modern colonialism in Antarctica: the coldest battle of the Cold War. In: Lehman, G. and D. Nichols (editors). Proceedings of the 7th Australasian urban history/planning history conference, Geelong, VIC: Deakin University, Australia: 72-95.

Decker, J. and C. Chiei (editors). 2005. Quonset hut: metal living for a modern age. New York: Princeton Architectural Press.

Dempewolff, R.E. 1961. Civilization comes to Antarctica. Popular Mechanics 115 (5): 104-109, 224, 226.

DoD (Department of Defense). 2004. Unified facilities criteria (UFC): Arctic and sub-Arctic construction buildings. Technical Manual TM 5-852-9 March 1988 (updated January 2004). Washington: Department of Defense. URL: http://www.wbdg. org/ccb/DOD/UFC/ufc_3_130_07.pdf, (accessed 1 August 2013).

DMJM. 2003. McMurdo Station long-range development plan June 2003 update. Washington: National Science Foundation Office of Polar Programs.

Dufek, G.J. 1957. Operation Deep Freeze. New York: Harcourt, Brace and World.

Easton, R. 1969. The Naval Civil Engineering Laboratory's polar engineering program. Antarctic Journal of the United States 4 (3): 73-76.

Ferraro, J.J. 2010. Development of a remote station architecture: McMurdo Station, Antarctica. Honolulu: Ferraro Choi and Associates. URL: http://ferrarochoi.com/publications/ development-of-a-remote-station/, (accessed 10 January 2011).

Harrowfield, D.L. 1995. Icy heritage. Christchurch: Antarctic Heritage Trust.

Hoffman, C.R. 1974. Engineering manual for McMurdo Station. Port Hueneme: Civil Engineering Laboratory.

Klein, A., M.C. Kennicutt II, G.A. Wolff and others. 2008. The historical development of McMurdo Station, Antarctica, an environmental perspective. Polar Geography 31 (3-4): 119144.

Lagerbom, C. n.d. America, Antarctica, and the American Polar Society. URL: http://www.americanpolar.org/polarcompendium/aps-history/, (accessed 7 October 2011).

Leshner, A.I. 2016. Don't forget the infrastructure. Science 352 (6286): 631 .

NRC (National Research Council). 1957. Antarctic program of the United States national committee for the International Geophysical Year, 1957-58. Publication 553. Washington: National Academy of Sciences.

National Security Council. 1970. National Security Decision Memorandum 71. Washington: National Security Council. URL: https://fas.org/irp/offdocs/nsdm-nixon/nsdm-71.pdf, (accessed 25 December 2015).

Neider, C. 1974. Edge of the world: Ross Island, Antarctica. New York: Doubleday.

NSF (National Science Foundation). 1996. Report on the US Antarctic Program, committee on fundamental science, national science and technology council. Document \# nstc96rp (Archived). URL: https://www.nsf.gov/pubs/1996/ nstc96rp/start.htm, (accessed 17 February 2013).

NSF (National Science Foundation). 1998. US Navy to depart US Antarctic program after 42 years. Press release 98-012, 18 February 1998. 
OPP (Office of Polar Programs). 1997. Report of the US Antarctic program external panel. Washington: National Science Foundation.

OPP (Office of Polar Programs). 2003. Housing and warehouse facilities at McMurdo Station Antarctica. Washington: National Science Foundation. URL: http://www.nsf.gov/ od/opp/usap_special_review/infrastructure_logistics.jsp, (accessed 11 January 2011).

Pearson, M. 1992. Expedition huts in Antarctica, 1899-1937. Polar Record 28(167) 261-276.

Planning for tomorrow at McMurdo Station. 1993. Antarctic Journal of the United States 28 (2): 4-6.

RSA. 2008. McMurdo Station energy upgrades. Book 1. Anchorage: RSA Engineering. URL: https://www.nsf.gov/about/ contracting/rfqs/support_ant/docs/femc_docs/mcmurdo_ energy_study.pdf, (accessed 11 February 2009).
Sherwood, G.E. 1964a. A temporary polar camp. Technical report Y-F015-11-104. Port Hueneme: NCEL.

Sherwood, G.E. 1964b. Temporary polar structures: modified T-5 barracks. Technical report Y-F015-11-149. Port Hueneme: NCEL.

Sherwood, G.E. 1965. Improvements to polar camps - use of a 64-foot Jamesway. Technical note N-771. Port Hueneme: NCEL.

US Department of the Army. 1957. Erection procedure for building, T-5, Arctic, prefabricated panelized, wood, 20 feet $x 48$ feet. Washington: Department of the Army.

USN (US Department of the Navy). 1968. Support for science: Antarctica. Washington: Department of the Navy.

Wilson, C.E. 1956. Operation Deep Freeze: first phase: 1955-56. Paoli: Dorville Corporation. 